\title{
Orden y memoria en la arquitectura contemporánea
}

\author{
Delfin Rodriguez Ruiz
}

\begin{abstract}
"Si un bello atrio, un vestibulo correspondiente, ó por último un aspecto total de una fachada, se pueden mirar como un discurso preliminar, ó como un prólogo en un escrito, no será infundado decir, que una portada puede mirarse como el primer vuelo de un poema".

Marqués DE URENAA, Reflexiones sobre la arquitectura, ornato y musica del templo, Madrid, 1785, pág. 219.

"... todas las formas tienen su virtud en si mismas, y no en un "contenido" conjetural".

Jorge Luis Borges, "La muralla y los libros", en Nueva Antologia personal, Barcelona, 1980, pag. 242.
\end{abstract}

Decía Gian Lorenzo Bernini, el gran arquitecto de la Roma barroca, que el principal mérito de un arquitecto no consiste en levantar edificios admirables y espaciosos, sino en sacar partido de los problemas, de los defectos, de los inconvenientes, de tal modo que, si esos obstáculos no existiesen, habría que inventarlos. Recientemente Quinlan Terry se preguntaba si «no representa un reto enfrentarse a cada problema nuevo partiendo de principios antiguos"'.

Arquitectura, Tradición y Clasicismo pueden ser entendidos como perfectamente intercambiables y de hecho asi ha ocurrido en muchos períodos de la historia de la arquitectura. Hoy el fenómeno parece generali-

"La afirmación pertenece a sus "Siete malentendidos sobre la arquitectura clásica", de 1981, véase B. J. ARChER y A. VIOLEH. Follies. Arquitectura para el paisaje de finales del siglo XX, Madrid, 1984, pág. 28. 
zarse y los problemas, cuando no existen, se inventan con el fin de encontrar una salida individual y sorprendente a la monotonía de la modernidad. De ahi que resulte tan complicado establecer parámetros críticos comunes para explicar la producción arquitectónica más reciente. Desde los oportunismos más fáciles a las más complejas elaboraciones teóricas y figurativas, lo que parece evidente es que el Clasicismo, o mejor, como ha escrito Teyssot, el arcaismo, "está de moda»².

En cualquier caso, el fenómeno señalado no es algo estrictamente reciente, aunque sí su carácter publicitario. Paralelamente al Movimiento Moderno, a veces en oposición, en otras ocasiones en polémica con él -pensemos en el clasicismo modernizado de la arquitectura de los años 30- la tradición y el clasicismo mantuvieron un atractivo coloquio con la vanguardia que, hasta tiempos recientes, ha sido sistemáticamente ocultado con el fin de defender la coherencia del racionalismo y del Estilo Internacional. Precisamente, uno de los mentores de ese último término, Philip Johnson, colaborador del gran Mies van der Rohe, a propósito de las pseudocolumnas monumentales de su Kline Tower de la universidad de Yale afirmaba, en 1973, que "es maravilloso y divertido sentirse pequeño. Amo la columnata de Bernini»3. Para tratar de entender la laberintica parábola del clasicismo arquitectónico durante el siglo $x x$ se hace cada vez más necesario el estudio de aspectos laterales, despiazados, silenciados, también con la finalidad declarada de constatar que la complejidad del arte moderno no puede ser reconducida a una sola historia.

\section{DE LOS ORIGENES AL POSTMODERNO}

La historia de la arquitectura contemporánea no puede ser durante más tiempo solamente una historia de lo nuevo y, en ese sentido, la permanencia de lo clásico, ya sea a través del historicismo, de la tradición Beaux-Arts o del productivo valor del contraste figurativo entre lo viejo y lo nuevo, constituye, sin duda, un apasionante capítulo no sólo para los historiadores sino, como se podrá comprobar, también para los arquitectos. Sin embargo, no puede negarse que una reconsideración semejante corre el riesgo de asumir complicidades polémicas ya que lo clásico mantiene aún connotaciones adjetivas singulares. Si leyéramos en cualquier

G. TEYssot, "Arqui-tec-tónico. La cuestión de los origenes», en Artifex, n` 3, 1984, págs. $17-26$.

${ }^{3}$ Entrevista a P. Johnson en J.W. Cook y H. KLoTz, Conversations with Architects, Nueva York, 1973. 
revista de arquitectura de los últimos años frases como estas: «la línea recta y el paramento plano han de ser las únicas reglas a seguir... La supresión total del capitei sería absurda y nos haría caer en el mal entendido racionalismo... El clasicismo es la perennidad de la forma...", no nos sorprenderian en absoluto. Las mismas fueron escritas por Diego de Reina en 1944, en su Ensayo sobre las directrices arquitectónicas de un estilo imperial. Pero también cabe recordar unas semiocultas casas schınkelianas construidas por Gropius, el gran abanderado del racionalismo, entre 1907 y 1910, a base de bloques cerrados, frontones, edículos con pilastras, etc., o la Embajada alemana en San Petersburgo, construida por Behrens y Mies en 1912, componiendo la fachada con un orden gigante toscano, o, cómo no, la invención de un nuevo "orden compuesto" por L. Kahn, que lo definia como un orden compuesto entre el ladrillo tradicional y el cementerio armado, y consistente en un segmento de arco con tirante, algo que ha sido muy utilizado con posterioridad, sobre todo en algunas recientes obras, paradigmas de 10 "romano".

Cada día se hace más necesario desvelar arbitrariedades como la de hacer derivar de Paxton la modernidad de Le Corbusier, en vez de hacerlo de algo mucho más próximo a su formación como es la tradición BeauxArts o su aprendizaje con Behrens.

En los primeros treinta años del siglo $x x$, la búsqueda de un nuevo comienzo para el arte no tenía más remedio que comprometerse con el clasicismo entendido como el arte del eterno comienzo. «En el arte en generai -escribía Sklovski-, y concretamente en los conjuntos arquitectónicos, lo importante son los choques, los cambios de señal, del mensaje". El mismo formalista ruso indicaba el supuesto, olvidado en favor de la coherencia de lo nuevo, de que "lo viejo queda en lo nuevo, es reconocible, pero recibe una nueva interpretación, adquiere alas, otras funciones " ${ }^{4}$.

Pero no estamos sólo ante una recuperación historicista y acrítica del clasicismo histórico, sino ante un apasionante debate con lo clásico, entre lo antiguo y lo moderno, que se formula de muy diversas maneras. Parece obvio señalar la banalidad de un tópico de la historiografia moderna en el que la crítica del clasicismo se hace desde instancias morales, en perfecto acuerdo con la tradición que ve en el racionalismo una opción ética y progresista. De este modo, por ejemplo, Benevolo señaló en su dia que la arquitectura de Tessenow, como antecedente de la arquitectura nazi, era moralmente despreciable.

Por un lado, el concepto ambiguo de "protorracionalismo" lejos de ser considerado como un momento de transición en el que perviven ele-

${ }^{4}$ V. SkLovSkı, La disimilitud de lo similar, Madrid, 1973, págs. 121 y 133. 
mentos tradicionales y, a la vez, anticipa soluciones nnsteriores, debe entenderse como una producción autónoma, específica, en polémica con el racionalismo y, además, coetánea de las obras de este último fenómeno.

Las citas, las analogias, los contrastes, la abstracción lingüistica, la memoria, la búsqueda de los origenes del construir, las distorsiones, la monumentalidad, son procedimientos desde los que se estudian aportaciones bien diferentes. Es más, el propio racionalismo del Movimiento Moderno aspiraba a convertirse en un nuevo clasicismo, en un nuevo estilo, de lo que tenemos buenas pruebas en la arquitectura de la Bauhaus, de Mies van der Rohe y en la codificación del Estilo Internacional.

Los ejemplos de Viena, del Deutscher Werkbund, de Perret, de Garnier, del doricismo escandinavo, de Plěcnik, de la polémica italiana, del ejemplo soviético, nos irán dando pruebas de la importancia del clasicismo ante la vanguardia, unas veces formulado como antivanguardia y otras comprometido con ella ${ }^{5}$. Como ha señalado Rowe recientemente, sin la base clásica no hubiera sido posible conducir el ataque de la modernidad. Racionalismo y urazón" clásica parecen condenados a discutir: la "cabaña rústica" de Laugier versus la Maison Domino de Le Corbusier.

La arquitectura como valor universal, el orden vitruviano, la pasión por la simetría (Tessenow señaló que nunca se podría hacer arquitectura si no se amaba profundamente la simetría y Wittgenstein reconocía en la simetría algo acabado, perfecto, que el hombre maneja a priori), son perfectamente reconocibles en muchas propuestas.

Por otra parte, con respecto al momento actual, y una vez convertidas en novelas de aventuras, las ambiguas y contradictorias proposiciones postmodernas nos han dejado una inestimable herencia: a partir de ahora el proyecto parece acercarse con mayor pasión e intimidad a la literatura. Pero no desde la importante y sugestiva tradición de las arquitexturas o arquitecturas literarias ${ }^{7}$, sino en un afán de hacer verosimil la desinteresada y altruista lucha de nuevos héroes, de nuevos e incomprendidos "pioneros". Aunque también es cierto que ante algunos textos no sabe-

b Sobre estos fenómenos la bibliografia se ha multiplicado en los últimos años, pero conviene tener en cuenta algunos importantes estudios: I. SOLA-MORALES, "Dal contrasto all'analogia", en Lotus international, n $\mathrm{n}^{\circ} 46,1985$, págs. 37-45; F. Borsi y E. Godol, Vienne. Architecture 1900. Paris, 1985; J. CLAIR (ed.), Vienne 1880-1938. L. Apocalypse joyeuse, Paris, 1986; W. OESCHLIN, "Contro la storiografia della "tabula rasa", en Rassegna, n 5, 1981 , págs. 36-41; L. PATETTA, La monumentalità nell'architettura moderna, Milán, 1982.

'C. Rowe, "Architettura e classicità" en V. Magnago LAmpugnani (ed.), Architettura moderna. L'avventura delle idee 1750-1980, Milán. 1985, págs. 80-82.

Sobre este último término véase Juan Antonio RAmirez, "Diecinueve puntos para una Arquitectura literaria", en Arquitectura, núm. 219. 1979, págs. 69-74. 
mos muy bien si estamos frente a una deliciosa novela o una nueva versión de la vieja tradición moderna de los manifiestos.

El mejor ejemplo de todo esto nos lo ha proporcionado recientemente un prestigioso historiador de la arquitectura, Paolo Portoghesi, que ha hecho de su último libro ${ }^{8}$ una reflexión autobiográfica en la que aparecen sucesivamente derrotados sus antiguos fantasmas.

También hay que señalar la frecuencia con que aparecen planteamientos y juicios inverosímiles, contradictorios, faltos de coherencia, y, a veces, amargos, incluso como bromas. Veamos dos ejemplos escogidos al azar de estas incomprensibles "bromas". En uno de ellos, Charles Jericks analizando la arquitectura de Aldo Rossi -a la que en otro lugar ha calificado de fascista (sic)-, señala: «En Italia, la experiencia del arquitecto moderno ha ido siempre estrechamente relacionada con la muerte. Varios racionalistas murieron en campos de concentración, otros diseñaron monumentos para patriotas, por lo que no es extraño que los temas mortuorios y las connotaciones de campos de muerte informen constantemente su obra»?.

El otro ejemplo nos lo proporciona Portoghesi al constatar la coincidencia de posturas entre el manifiesto del Sindicato Solidaridad y el Postmoderno (?). Afirmación que es más incomprensible aún cuando casi todos estamos de acuerdo en el fracaso de una idea difundida por el Movimiento Moderno: la relación dialéctica entre vanguardia artística y vanguardia política, como forma idónea de secundar un cambio de estructuras y de comportamientos.

El debate que se encierra detrás de esta fachada es muy complejo y por eso mismo se nos hace cada vez más difícil entender que todo él pueda reducirse a una fórmula afortunada que tiene en su punto de mira al Movimiento Moderno; sobre todo, cuando tampoco éste puede considerarse un todo homogéneo, como ha demostrado la más reciente historiografia.

8 Paolo Portoghesi, Postmodern: L'architettura nella società postindustriale, Milán, 1982. Ed. Electa. Un análisis sobre la crisis del Movimiento Moderno puede verse en una obra anterior de PoRtogheSI, Dopo l'architettura moderna, Ed. Laterza, Roma-Bari, 1980.

9 De Charles Jenks parece inútil recordar tres libros conocidísimos: Movimientos Modernos en Arquitectura, Blume Ed. Barcelona, 1983; El lenguaje de la arquitectura postmoderna, Ed. Gustavo Gili, Barcelona, 1980, y Arquitectura tardomoderna y otros ensayos, Ed. Gustavo Gili, Barcelona, 1982. La afirmación se encuentra en Ch. JENKS, «Racionalismo irracional. Los rats desde 1960", en Arquitectura tardomoderna... op. cit., pág. 133. En un sentidc muy distinto es interesante ver las relaciones entre lo funerario y la arquitectura tal como se plantean en un número monográfico de la revista Lotus International, núm. 38, 1983. 
Ya hemos señalado en otro lugar ${ }^{10}$ que la relación con la historia, a veces para negarla, es uno de los elementos claves para entender la arquitectura contemporánea que, al mismo tiempo, pretendía conservar su carácter artístico en medio de la disolución metropolitana, a pesar de multitud de pronunciamientos en sentido contrario.

En el momento actual, después del postmoderno, nos quedan precisamente las inquietantes arquitecturas y proyectos de los últimos años y con ellos dos o tres problemas decisivos para el futuro (un futuro en el que el elemento prioritario del debate será el de la pasión por la forma, tema ya viejo en la historia de la arquitectura). Problemas que podemos precisar polémicamente como los de la "ejemplaridad del dórico" -entendido como paradigma de la naturalidad de lo clásico-, la pureza como verdad y valor de Mies y el estadillo autobiográfico del diálogo con la historia de Le Corbusier.

La actividad arquitectónica más reciente no hay que leerla sólo como una respuesta acorde con un eclecticismo radical que se convierte en caricatura cuando se quiere ver en él una nueva norma. Tampoco el mito de un nuevo orden, de un nuevo código referencial explícito, equilibrado y sancionado por las permanencias formales y tipológicas de la historia, tiene mucho sentido. Tal vez habría que ver en la nueva arquitectura una voluntad de presentarse conscientemente como fragmentos.

Es necesario que aclaremos algo más sobre esta idea. Si el movimento moderno habia planteado sus arquitecturas como fragmentos de una utopia de control figurativo y de comportamientos de la gran ciudad, las últimas arquitecturas se presentan como fragmentos de un collage y esto sólo en el sentido de una ciudad donde los significados y las formas colisionen simbólicamente, como recientemente ha propuesto Colin Rowe ${ }^{11}$, sino que la ciudad acoge y selecciona los fragmentos de un collage definido por la permanencia de la historia. En este supuesto cabe además la posibilidad de hacer converger los intereses de una arquitectura de la ciudad, en el sentido que le han querido dar Aldo Rossi y la Tendenza, con los de una arquitectura que se refiere a si misma en cuanto historia.

Clasicismo e historia vuelven a ser elementos decisivos para el proyecto: la pasión por los elementos y por su articulación se vuelven a proponer como base de la meditación sobre la forma de la arquitectura y de la ciudad. Pero se trata de un clasicismo que no es sinónimo de orden ni

10 Ver El siglo XX. Entre la muerte del arte y el arte moderno, Ed. Istmo, Madrid, 1982.

11 Colin Rowe y Fred Koetrer, Ciudad Collage, Gustavo Gili, Barcelona, 1981. De Collin ROWE conviene releer con frecuencia, sobre todo en estos momentos, su Manierismo y arquitectura moderna y otros ensayos, Gustavo Gili, Barcelona, 1978. 
de cita culturalista y arbitraria; al contrario, estamos ante un clasicismo crítico que lleva en sus propias contradicciones la razón del eclecticismo. $Y$ este es un debate abierto desde el siglo XVII y que la reciente tradición de las Beaux-Arts no supo resolver. Sólo con una aparente negación de la historia se quiso cerrar este debate y ahora, como negación de esa negación, algunos vuelven a proponer una cuestionable reactualización del clasicismo con un marcado idealismo que en su afán de justificarse en la realidad de la producción masiva e indiscriminada de viviendas y con un sentido instrumental del lenguaje clásico han propuesto la inverosímil idea de un "clasicismo proletario". Sin entender que la especificidad de lo clásico tiene poco que ver con la máscara y con el maquillaje, Charles Jencks ha adoptado este término, en su incesante innovación publicitaria, para explicar el Palais d'Abraxas de Ricardo Bofill en Marne-la-Vallée'2.

Orden y memoria, como portadores de una elocuente calma y meditación, no pueden reducirse al esquematismo ahistórico de simplificar las complejas relaciones que ha establecido la tradición clásica entre mímesis, tipo y lenguaje en una espectacular fórmula: "El clasicismo del hormigón puede imitar el clasicismo de la piedra, que imitaba las construcciones de madera"' ${ }^{3}$.

Los problemas formales del clasicismo y de la historia aparecen en algunos proyectos utilizados como citas, ya sea con un carácter lógico o evocador, con una intención polémica o como juego arbitrario, con el sentido de defensa de las agresiones de la gran ciudad o con el de perpetuar la artisticidad como reacción pedagógica, y como una manera de ahogar la modernidad. La cita tiene a lo largo de la historia su máxima ejemplaridad cuanto más se independiza de la función del nuevo contexto. De ahi que las referencias, por parte del neorracionalismo de Rossi, Grassi o la Tendenza, al tipo como programa, recogiendo la tadición de Durand ${ }^{14}$, corra el riesgo de reducirse a modelo (lección fácil de aprender en todas las Escuelas de Arquitectura), a no ser que recupere el significado histórico

12 Charles JENKS, "Le classicisme Free Style à la française", en AA.W, Architectures en France. Modernité/Post-Modernité, Centre Georges Pompidou, Paris, 1981, pág. 33.

13 lbidem, págs. 32-33.

14 Sobre este tema es importante consultar el prólogo de Rafael Moneo a la edición española de J.N.L. Durand, Compendio de lecciones de Arquitectura. Parte Gráfica de los concursos de Arquitectura, Ed. Pronaos, Madrid, 1981, págs. V-XIII, donde señala: "Escribir un tratado como el de Durand se ha convertido en la ambición de más de un arquitecto contemporáneo al pensar que la disciplina no adquirirá hoy su madurez hasta que no sea capaz de codificar sus principios y de ofrecer un método de proyecto tal como Durand hizo.

Olvidan, quienes alimentan tales fantasias, que Durand contaba todavia con los restos del naufragio, con los elementos de la arquitectura clásica. Las circunstancias son hoy bien diversas y la admiración que todavia la obra de Durand produce no debe llevar, en mi opinión, a la simple emulación mimética". 
de los tipos, entendiéndolos como citas o que se aventure en una tarea de más altos vuelos sobre el problema de la forma como lenguaje. $Y$ en relación a esto, los ejemplos, como veremos, comienzan a multiplicarse.

Es posible que uno de los aspectos más atractivos de la última arquitectura sea el de no mirar al pasado sólo como un surtido almacén del que recoger elementos, sino de ver en él la posibilidad de recuperar viejos temas de meditación que, sin ser funcionales, obligan a un ejercicio autónomo de la arquitectura, a volver a pensar lo ya pensado y diseñado como si en esa aparente rutina estuvieran encerrados los secretos más íntimos de la disciplina. Es por esto que cada vez tiene menos sentido mantener un tipo de actitudes que podrían sintetizarse en la dramática imagen de un cuadro de Chagall en el que un impetuoso revolucionario se dispone a destruir un convencional palacio, como simbolo de la degeneración. La obra, de 1919, lleva un elocuente título, Paz a las cabañas, guerra a los palacios, y resume uno de los más divulgados tópicos del Movimiento Moderno.

Pero esas críticas a la impureza, a lo contaminado, no son sino la búsqueda de un nuevo punto de partida que no siempre estuvo bien definido, ni tan siquiera en las actitudes más radicales. La propia experiencia del Movimiento Moderno ha demostrado que el optimismo puesto en las consecuencias del desarrollo tecnológico y de la transformación social sólo pudo hacerse verosímil en los lenguajes y eso significaba hacer estallar simbólicamente los tópicos más consolidados. Es más, Le Corbusier se da cuenta muy pronto de este problema y cuando en Vers une Architecture, de 1923, plantea el dilema entre Arquitectura o Revolución, opta por la primera haciendo que su radical antihistoricismo, -entendido como un desplazamiento de conceptos según la atinada observación de A. Colquhoun ${ }^{15}$ no incluya una polémica anticlásica.

La arquitectura contemporánea ha ofrecido una enorme variedad de soluciones diferentes, de poéticas contradictorias y de compromisos complejos, unas veces defendiendo la intimidad y elocuencia de los lenguajes y otras lanzándose a un prometedora disolución en la ciudad, en la planificación. En conjunto, la arquitectura y la ciudad se han construido desde diferentes valoraciones que han permitido una pasión por los simbolos y significados no siempre conscientemente asumidos y, en su heterogeneidad, esos intentos de hacer de la arquitectura un intermediario privilegiado entre las aspiraciones colectivas y las formas de manifestación del poder nos obligan a estudiar la historia como una multitud de historias.

is A. Colouhoun, "Desplazamientos de conceptos en Le Corbusier", en Arquitectura moderna y cambio histórico: Gustavo Gili, Barcelona, 1978, págs. 113-126. 
Después de tantos años de utilizar el convencional término de Movimiento Moderno para explicar lo ocurrido desde los inicios de siglo, se ha llegado a la conclusión de que se trata de una etiqueta que no explica casi nada. Son tantas y tan variadas las propuestas, los proyectos y las realizaciones prácticas que la riqueza de los lenguajes no puede reducirse en los estrechos márgenes de una consigna. Es más, cuando nos acercamos a ese pasado heroico, lleno de sueños, utopias y miserias, hay que señalar que el legado más importante lo ha constituido una inquietante presencia de lenguajes rotos, de formas inexpresivas, de ciudades que han perdido su identidad figurativa y morfológica.

Volver a pensar en la forma y en la tipologia significa aceptar que la tradición ha pervivido, manifestándose de diferentes maneras en el seno de las vanguardias y del Movimiento Moderno, unas veces con nostalgia y otras como una secreta aspiración a construir un nuevo clasicismo que, aparentemente enfrentado con la memoria, se hizo inevitable detrás de ropajes seducidos por el mito de la máquina. También es cierto que la pantalla figurativa e ideológica de todas esas innovaciones continuas modifica la nueva pasión por la especificidad de la disciplina, por su propia historia. Y ya que ni la tradición Beaux-Arts está cerrada y el lenguaje clásico atrae a muchos arquitectos, es preciso señalar que el coloquio con la historia de la arquitectura y de la ciudad no puede reducirse a una generalización de principios estables (como quisieron algunos arquitectos de los años veinte y treinta) ni a la configuración de una nueva Academia.

Con todo ello, resulta cada vez más atractivo rastrear problemas relativos a la utilización e instrumentalización de los lenguajes y de las citas, con el fin de revelar las posibilidades encerradas en la permanencia de significados formales y tipológicos $O$ en su reelaboración critica en la construcción de la ciudad. Clasicismo, Eclecticismo, tradición Beaux-Arts, Academia, la Nueva Babilonia del Movimiento Moderno y la idea de una arquitectura seducida por las maravillas ${ }^{16}$, por los monumentos, por la evocación de las permanencias urbanas, son otros tantos problemas que es-

${ }^{16}$ Esta referencia a las maravillas se ha planteado desde una poetica de la memoria que distorsiona significativamente el orden del proyecto, continuamente enriquecido por la presencia de arquetipos y mitos de la historia de la arquitectura, por temas de obsesión permanente e imposibles de reducir a la totalidad del modelo. En este sentido es sumamente atractivo un collage sobre la historia de la arquitectura realizado por Burkhard Grashorn en 1978 y expuesto en la muestra "La presenza del Passato" de la Bienal de Venecia de 1980. En él aparecen el Templo de Salomón, la Torre de Babel o el Cementerio de Módena de Aldo Rossi, entre otros edificios. Una reproducción de la obra de Grashorn puede verse en el catálogo de la exposición La presenza del Passato, Electa Ed., Milán, 1980.

En èl no hay alusión alguna al caos metropolitano, al desorden figurativo, como ocurre en otro collage de 1922, titulado Metrópoli, obra de Paul CiTroen, un alumno de la Bauhaus, a 
tán abriendo un apasionado debate que muchos quisiéramos cargado de historia. Se trata de recuperar la ciudad, de enfrentarse a la metrópoli, con la arquitectura y no de disolverla en la ideologia del Plan convirtiéndola en objetos anónimos que están, a pesar de un voluntarismo vanguardista y de la inevitable lógica del poder, en una permanente angustia por conservar su carácter artístico y simbólico.

Se puede hablar de la existencia de una voluntad de reconstrucción en la que la ironia no pueda ser sinónimo de mascarada y donde antes de saltar por encima de la historia de nuestro inmediato pasado hay que mirar de una manera distinta las sorpresas contenidas en las posturas radicales y en los edificios construidos por el Movimiento Moderno en la Nueva Babilonia. Además, esta reconstrucción debiera ser formal -una forma cargada de memoria que se aleje del riesgo del monótono formalismo figurativo y del simulacro-, como el medio idóneo de encontrar una más adecuada articulación con la ciudad y con la historia, ya nunca más entendidas como modelos abstractos, como instrumentos de un discurso.

\section{EL LABERINTO DE LO CLASICO}

La crítica que desde dentro de la tradición moderna se comienza a hacer, a partir de los años cincuenta, a las consecuencias formales y tipológicas del racionalismo funcionalista, que en ocasiones evocan el mito del clasicismo, estaba destinada a centrarse en una renovación de la forma como portadora de nuevos significados. Devolviendo la calidad a la manipulación de los materiales y enriqueciendo la articulación de los lenguajes, la imagen de la modernidad arquitectónica -pensemos en los brillantes ejercicios autobiográficos de recuperación de estímulos dispares de Le Corbusier, en la valoración desinhibida de los materiales constructivos del Nuevo Brutalismo o en la recomposición de piezas y elementos de calma histórica de Louis Kahn- se ve empujada hacia una elocuencia figurativa que se aleja progresivamente de la idea de una arquitectura entendida como caja contenedora de funciones indiferentes y de la uniformidad visual y de la monotonia.

cuyo carácter emblemático, en relación al Movimiento Moderno, ya hemos hecho referencia en otro lugar. Véase El siglo XX. Entre la muerte... op. cit., págs. 131-132. En cualquier caso, el sentido de la meditación sobre las maravillas no puede plantearse como una opción "operativa" y ahistórica como pretende Jencḱs al señalar que "Bofill está decidido a realizar la octava maravilla del mundo...", o puede que sea inevitable que estemos obligados a construir esa octava maravilla desde Juan de Herrera a Bofill. Véase Ch. JENCKS, Movimientos Modernos..., op. cit., pág. 384 . 
Ni la valoración de la metrópoli como un sucederse de episodios monumentales -reducida la idea de monumento a la presencia de los grandes rascacielos-, ni la huida hacia una utopía tecnológica, podian expulsar el temor de una definitiva pérdida de la identidad de la arquitectura como institución. Hacer estallar el orden, tanto desde una voluntad de continuidad crítica con la tradición moderna que busca una adecuada articulación con la ciudad inaugurando inéditas modificaciones figurativas, como desde una recuperación angustiada de episodios expresivos y olvidados de la tradición moderna -Art Nouveau, Expresionismo, Arquitectura Orgánicacon la intención de interiorizar un intimismo imposible, conduce inevitablemente a un progresivo acercamiento a la especificidad disciplinar, a entender la arquitectura como un lenguaje cargado de historicidad, en sintonía con las permanencias urbanas y con una voluntad de devolver el carácter colectivo y "civil" a la imagen de la ciudad.

Ya no es la ideologia del Plan la que justifica la arquitectura sino que es ella la que construye la ciudad. Con la aparición a mediados d los años sesenta de dos decisivos libros, uno de R. Venturi ${ }^{17}$ y otro de Aldo Rossi ${ }^{18}$, aunque desde posturas opuestas, aparece de una manera consciente el problema de la relación con la historia, en un intento complicado de clarificar la angustia del proyecto, de devolver la autonomia a la arquitectura. Si la atormentada valoración de códigos ajenos al orden están presentes en la precipitada utilización de la memoria como máscara publicitaria, significativamente unida a una versión pop de la imagen, que propone Venturi, la meditación rigurosa de Aldo Rossi, Giorgio Grassi ${ }^{19}$ y, en un sentido más intimista, Rob $\mathrm{Krier}^{20}$, abre el camino a una no ocultada pasión por la racionalidad de lo clásico y por devolver un orden a la memoria. El camino quedaba libre para la eclosión de diferentes y contradictorias propuestas de resemantización de los lenguajes ${ }^{21}$.

Plantear estos problemas favorece una atractiva revisión de la permanencia, como cita o como alusión, de la tradición clásica en el interior del Movimiento Moderno y fuera de él. Sobre este punto es importante señalar una decisiva observación: la pervivencia -por utilizar un término al uso en

17 R. VentuRI, Complejidad y contradicción en arquitectura, Ed. Gustavo Gili, Barcelona, 1974.

18 Aldo Rossi, La arquitectura de la ciudad, Ed. Gustavo Gili, Barcelona, 1976 y también Para una arquitectura de tendencia. Escritos, 1956-1972, Ed. Gustavo Gili, Barcelona, 1977.

19 Giorgio Grassi, La construcción lógica de la arquitectura, Publicaciones del Colegio Oficial de Arquitectos de Cataluña y Baleares, Barcelona, 1973.

${ }^{20}$ De Rob Krief pueden verse El espacio urbano. Proyectos de Stuttgart., Ed. Gustavo Gili, Barcelona, 1976 y Sobre la arquitectura, Ed. Gustavo Gili, Barcelona, 1983.

21 Sobre este tema véase el interesante articulo de Manfredo TAFURI, "Les cendres de Jefferson", el L'Architecture d'aujourd'hui, $\mathrm{n}^{\circ}$ 185, 1976, págs. 53-58. 
la historiografía de la arquitectura tradicional en el siglo $x x$ no ha supuesto que la construcción de la ciudad haya sido fruto de un proceso dialéctico con el Movimiento Moderno y las vanguardias. Al contrario, las construcciones tradicionales se han alejado conscientemente del problema de la ciudad, de la construcción de la metrópoli, encerrando sus significados en un contexto aislado y beligerante, por muy frecuentes que fueran. Su último afán consistió en decorar un nuevo poder, que fue renunciando a su lenguaje progresivamente, con elementos figurativos antiguos, en un intento de buscar una continuidad idealista de los significados culturales de que eran portadores en otros momentos históricos ${ }^{22}$. Un estudio atento de esta arquitectura revelaría aspectos estimulantes, aunque en este caso lo que nos interesa analizar es una dialéctica real, en el seno de la vanguardia, entre nuevas formas y elementos compositivos y alusiones clásicas, en una relación conflictiva con la metrópoli. Una vanguardia que, comprometida con las transformaciones técnicas, constructivas y sociales, no olvidó, a pesar de su declarado antihistoricismo, los grandes problemas que la cultura arquitectónica del pasado dejó sin resolver. Es más, muchos de ellos fueron planteados con una apariencia figurativa radicalmente nueva $y$, en ocasiones, fueron recuperadas citas concretas que con una intención polémica eran incluidas en contextos nuevos.

El sentido último de esta manera de entender el coloquio con la historia, tanto en el Movimiento Moderno como en las últimas propuestas, podria resumirse brevemente con una doble alusión metafórica: en primer lugar, es ilusorio plantear modelos ideales de continuidad entre dos momentos históricos, apoyándose en un hipotética afinidad de intereses entre la arquitectura de la llustración, reducida a un proyecto que se justificaria en la autonomía de la disciplina, en la racionalidad del programa y en un compromiso social y ético que anticiparia un cambio revolucionario, y el racionalismo funcionalista del siglo $x x-D e$ Ledoux a Le Corbusier, por utilizar el feliz titulo de la conocida obra de Kaufmann ${ }^{23}-$. Una sugerente

2. Sobre la importancia de esta obra historia de la arquitectura del siglo $\mathrm{xx}$, ver las interesantes páginas, aunque lejos del sentido que le hemos dado en el texto, dedicadas al tema por Henry-Russel HITCHCOCK, en 1958, en Arquitectura de los siglos XIX y XX. Ed. Cátedra, Madrid, 1981, donde señala que las crealizaciones tardias y anacrónicas, en caso de reconocerse, se han adjudicado un tanto injustamente, a la época anterior... Pero esta historia no es fácil de contar porque parece -al menos a la mayoría de los eruditos de hoy dia- que carece de argumento. Por otro lado, el nacimiento de la arquitectura moderna es un buen material para un narración dramática, pues sigue la pauta de las "historias de éxito", como la historia del gótico del siglo xlı en Francia o los comienzos del Renacimiento en Italia en el siglo XV”.

${ }^{23}$ E. Kaufmann escribió su libro en 1933 desde la óptica de una crítica militante. En él señalaba que la arquitectura de Ledoux "constituye el primer manifiesto de las nuevas finalidades artisticas, testimonio evidente del formarse de un nuevo mundo. Demostraremos después cómo sus nuevos conceptos y los de su tiempo persisten todavia en nuestros dias y 
propuesta que renuncia a considerar precisamente la herencia más apasionante que recibió la arquitectura moderna, configurada en torno a la Academia, al Eclecticismo y la tradición Beaux-Arts ${ }^{24}$. Por otra parte, las referencias figurativas pueden venir de cualquier momento para hacer más elocuentes los nuevos problemas, pero los significados se han modificado, aunque los grandes temas de la disciplina pervivan.

En segundo lugar, el nuevo coloquio con la historia permite valorar con un análisis diferente la complejidad de las arquitecturas del poder en los regímenes totalitarios del siglo $\mathrm{x}^{25}$, sin caer en el peligro de considerar inocentes todas las recuperaciones historicistas.

En este estimulante panoraria que intenta una lectura de lo clásico, de su instrumentalización y de su posible eficacia, desde los primeros momentos de enfrentamiento radical con la historia y de un compromiso por la construcción de un nuevo lenguaje, de una nueva utopia, hasta los más brillantes ejercicios con lo clásico de la actualidad, dejaremos intencionadamente al margen un punto decisivo de esta dialéctica que sería apasionante estudiar, aún cuando no esté presente por razones obvias en los tableros de los arquitectos. Un punto que complicaría radicalmente el coloquio con la historia al introducir elementos tan inestables como el gótico, el expresionismo, la arquitectura de cristal y los modelos orientales.

Las referencias a la tradición clásica tarito en los arquitectos del Movimiento Moderno como en las distintas poéticas de la memoria de los últimos años, tienden a no comprometerse con un tipo de revival siempre dispuesto a la recuperación de los ideales de pureza del modelo. A lo largo de la historia de la arquitectura los elementos clásicos han sufrido investigaciones diferentes e, incluso, contradictorias. Es por eso por lo que cada vez tiene menos sentido la nostalgica idea de que la arquitectura vuelva a someterse a un utópico orden que nunca fue real. Es más, la historia de los diferentes clasicismos es más la historia de una aspiración a lo clásico que una reac-

cómo en tal modo la unidad de los últimos ciento cincuenta años se refleja en los hechos de la arquitectura". Ver E. KaUfMANN, Da Ledoux a Le Corbusier. Origine e sviluppo dell'architecttura autonoma, Gabriele Mazzotta Ed., Milán, 1973, pág. 11.

${ }^{24}$ Sobre este tema puede consultarse el trabajo de I. SOLA MORALES, "De la memoria a la abstracción: La imitación arquitectónica en la tradición Beaux-Arts", en Arquitectura, núm. 243, 1983, págs. 56-63.

${ }^{25}$ En los últimos años se han multiplicado los trabajos sobre estas arquitecturas, aunque con frecuencia se recurre al dificil equilibrio de aislar la arquitectura de la ideologia y de la historia con el fin de lograr un estudio en el que no pueda tener cabida el tópico de la condena moral. Siendo la bibliografia inmensa, sobre todo con respecto a Italia, España y la Unión Soviètica, aqui sólo mencionaremos un ensayo modélico, el de G. Cluccl «ll dibattito sull'architecttura e la città fasciste", en W.AA. Storia dell'Arte Italiana. /" Novecento, Einaudi Ed., Turin, 1982, págs. 263-378. 
tualización constante de principios básicos como el del "procedimiento racional" que "controle la invención", como propuso en $1963 \mathrm{~J}$. Summerson $^{26}$. Precisamente, la utilización de la memoria histórica se alza contra la idea de un modelo universal: las meditaciones sobre el clasicismo presuponen la crisis de principios estables de orden ${ }^{27}$.

En los primeros decenis del siglo se establece una relación con la tradición clásica en la que, lejos de pretender la codificación de invariantes básicos, que reproduzcan articulaciones formales tradicionale ${ }^{28}$, se busca un nuevo equilibrio compositivo basado en una simplificación formal y en una clara definición de la planta, como elementos claves para la construcción de un nuevo clasicismo en la metrópoli. Frente a la indiferencia formal y figurativa del alzado con respecto al orden geométrico de la planta, propuestas por Durand, la idea que plantean algunos arquitectos parece recuperar otro punto importante de la cultura arquitectónica del siglo XVIII que puede resumirse en las palabras de un casi desconocido profesor de la Academia de San Fernando de Madrid, Joseph Moreno: “De la planta viene originariamente la bondad de una fábrica; y rara vez se encontrará defecto esencial en la forma, que no provenga de la planta» ${ }^{29}$.

El tema de la planta como determinante del carácter formal del edificio tuvo un interlocutor privilegiado y de enorme influencia en Hans Poelzig ${ }^{30}$, a propósito de su concepción de la arquitectura como artificio -en el que la aristotélica idea de la mímesis y de la relación con la naturaleza eran modificadas como consecuencia de una lógica constructiva que buscaba su significación en el caos de la gran ciudad- señala, en 1931, que cel verdadero ornamento es simbólico, la columna antigua es música pura, es completamente innatural'. Pero no todas las referencias a lo clásico tienen el mismo sentido.

La imagen de una arquitectura apoyada en la proporción, el equilibrio y la calma figurativa estuvo en la base de otras propuestas. También la cita de elementos aislados en contextos nuevos, ya fuera como último

\footnotetext{
26 John Summerson, El lenguaje clásico de la arquitectura, Ed. Gustavo Gili, Barcelona, 1978, págs. 89-90.

${ }^{27}$ Contrariamente a esta idea, y llevando a sus últimas consecuencias la idea de Grassi de la "construcción lógica de la arquitectura", puede verse J.L. LINAZASORO, El proyecto clásico en arquitectura, Ed. Gustavo Gili, Barcelona, 1981.

${ }^{28}$ En un interesante trabajo, Adolf Max VOGT ha señalado una serie de temas formales recurrentes en las distintas fases del clasicismo que irian desde la columna al podio o el frontón. Véase A.M. VOGT, "Le fasi storiche dell'architettura neoclassica", en Bolletino del Centro Internazionale di Studi di Architettura Andrea Palladio, núm. XII, 1971, págs. 75-91.

${ }^{29}$ Josep MOReno, Viage á Constantinopla, Madrid, 1790, pág. 174.

${ }^{30}$ Sobre las relaciones entre Poelzig y Mercadal ver el estudio de C. SAMBricio, "Garcia Mercadal. Pretexto/Calembourg, Catepac G.C.», en Cuando se quiso resucitar la arquitectura, Murcia, 1983, págs. 95-171.
} 
lamento por una pérdida irreparable, o como sublime ironia, tuvo otros adeptos. Por otro lado, son numerosos los proyectos y realizaciones que retoman la idea del repertorio clásico para hacer un discurso intelectual sobre la especificidad de la arquitectura en dialéctica con la revolución figurativa y tecnológica de las vanguardias, especialmente en polémica con el constructivismo soviético y con el futurismo italiano. Esta última imagen de aparente «regreso al orden" permitió a muchos mediocres y reaccionarios arquitectos sumarse acríticamente a un debate apasionante. Es más, los historiadores y críticos han condenado globalmente esta recuperación merced a una lectura poco atenta y rigurosa, y sólo en los últimos años se ha iniciado una revisión historiográfica interesantísima.

Los tres modos de apropiación de la tradición clásica apuntados brevemente sirven para ordenar la complejidad de esta oculta vocación de la arquitectura contemporánea. La indecisión que atrapa estas arquitecturas no obedece exclusivamente a un conflicto entre los lenguajes sino, sobre todo, a un conflicto con la organización de la ciudad. El eclecticismo latente en la tradición clásica pudo convertirse, paradójicamente, en el arma más adecuada para combatir el afán de universalismo del racionalismo funcionalista. El sentido de esa utilización de lo clásico tenía poco que ver con la de los primeros maestros del racionalismo que pretendian un control de la imagen de un proyecto que se les escapaba. De este modo no resulta sorprendente que Behrens intentara equilibrar el mito de la unidad entre arte y técnica con una apariencia de clasicismo simplificado en edificios como la Fábrica AEG, construida en 1909 en Berlín. El lenguaje de Behrens pretendía ennoblecer, con una marcada indiferencia de la forma hacia la función de las tipologias y llenar de contenido simbólico la construcción. Una actitud lógica si pensamos que, a pesar de sus buenos propósitos, confundía tipificación con tipología: trataba de controlar el diseño desde el orden de la simetria y de la calma, como ocurre en su Casa Cuno, construida en Eppenhausen, también en 1909, con un edículo central semicircular, con pilastras, que divide en dos partes la fachada.

En la fábrica AEG, Behrens construye un templo del trabajo, simplificando y clarificando la tradición clásica, donde se indican varias cuestiones: por un lado, controla en términos de fachada un edificio que no precisaba de tales soluciones; por otro, inaugura una afortunada solución, reduciendo a su mínima complejidad, como forma de asegurarse una via hacia la arquitectura pura, una estructura clásica rica de articulaciones como es la relación entre pilastra, arquitrabe y frontón: el frontón poligonal descansa $\sin$ intermediarios sobre unas pilastras falsas ${ }^{31}$-un tema al que recurri-

\footnotetext{
${ }^{31}$ Ludwig Hilberseimer, en 1927, enjuiciaba asi la obra de Behrens: "Peter Behrens, inducido por la politica imperialista de preguerra y frenado por las influencias clasicistas, creyó
} 
rán varios arquitectos, entre ellos Josef Hoffmann en el pabellón de la Exposición del Werkbund, y que tendrá su versión más elaborada en el frontón y las columnas metálicas del radiador del Rolls Royce en 1932. Este desconocido motivo ha sido utilizado como monumento elocuente e irónico al clasicismo tecnológico más depurado en un curioso fotomontaje de Hans Hollein, realizado en 1966, en el que el radiador es convertido en rascacielos y situado en Wall Street-, y, por último, plantea estas alusiones como la única manera de convertir en arte la arquitectura: un discurso que él separa, a raíz de su experiencia urbanística en la Viena socialdemócrata de los años veinte, de los problemas utilitarios ${ }^{32}$.

Las distintas, y hasta opuestas, manipulaciones de elementos clásicos de algunos de los arquitectos más importantes de los primeros años del siglo, tenian que plantearse en dialéctica con la vanguardia y en oposición a ella. Sus arquitecturas podían formar parte de un particular museo que sólo tuviese como misión acoger obras que sintetizasen aspiraciones y referencias múltiples, que representase situaciones límite que condensaran problemas dispares. $Y$ un museo de este tipo no se podria construir nunca desde la hipótesis de una nueva Roma, sino, como proyectó Le Corbusier, a partir de una nueva Torre de Babel ${ }^{33}$.

La variedad y riqueza de los proyectos contaminados por la tradición es enorme. Desde la construcción de un nuevo clasicismo helénico para la ciudad industrial -haciendo coincidir, en una imposible sintesis, la nostalgia de una hipotética edad de oro con la utopia de un control figurativo y equilibrado de la ciudad del capital- de Tony Garnier, hasta la idea de una

necesario añadir una fachada a su nave de turbinas de la AEG en Berlín-Moabit, un edificio, sin ella, ya lleno de fuerza. Para ello construyó las esquinas de la nave de hierro con enormes sillares, con la intención de crear un contraste material y estático que produjesen un efecto arquitectónico y una impresión imponente. Pero estas pilastras a modo de sillares, que producen la impresión de un enorme peso, no son apoyos, sino, como se ve en la planta, una fina lámina de hormigón armado; son un intento de usar las nuevas posibilidades ténicas como un medio para conseguir impresiones arcaicas, un tema tipico de fachada, esfuerzo para simbolizar sensaciones poco claras y fuerzas inexistentes, voluntad de querer colocar lo representativo por encima de lo orgánicamente caracteristico". Véase L. HILBERSEIMER, La arquitectura de la Gran Ciudad. Ed. Gustavo Gili, Barcelona, 1979, pág. 91.

32 En 1928, en un artículo titulado "El Ayuntamiento de Viena como comitente", Behrens indica que uen la construcción de casas de habitación se trata siempre de entender la tarea de un modo objetivo y cumplido, y no de resolver cuestiones artisticas". El texto está recogido de M. TAFuRI, Vienna Rossa. La política residenziale nella Vienna socialista, 1919-1933, Electa Ed., Milán, 1980, pág. 233.

${ }^{33}$ El proyecto de Le Corbusier de 1928 era un Museo Mundial en forma de espiral cuadrada ascendente que formaria parte de una nueva ciudad mundial, el Mundaneum, a construir en Ginebra a partir de una sugerencia de Paul Otlet. Sobre el tema véase Marcello FAGIOLO, "La nuova Babilonia secondo Le Corbusier", en Notiziario Arte Contemporanea, 1974, págs. $15-17$. 
arquitectura como ensayo de LOOS, que se opone tanto a la ortodoxia de lo nuevo como a la tradición de lo viejo, y en la que las referencias al lenguaje clásico tienen siempre un sentido de excepcionalidad monumental que ilustra la imagen de la nueva ciudad propuesta en su conocido Ornamento y delito, de 1908: “Ved, está cercano el tiempo, la meta nos espera. Dentro de poco, las calles de las ciudades brillarán con muros blancos. Como Sión, la ciudad santa, la capital del cielo".

Garnier, alumno de Guadet, realiza una espléndida sintesis entre la tradición Beaux-Arts y el equilibrio compositivo y formal de sus dibujos. Sus construcciones adquieren su carácter gracias a una elaborada manipulación de los nuevos materiales. Entre la iglesia votiva proyectada en 1899 y los dibujos de su Ciudad Industrial sólo han pasado unos pocos años: clasicismo y modernidad aparecen resueltos y unificados en un acritico e ilusorio lenguaje sin fisuras que tendria su continuidad en obras posteriores en las que una sintesis clasicista entre la tradición antigua y la francesa eran evidentes ${ }^{34}$.

Loos, sin embargo, récurre a la cita clásica con un sentido más angustiado y sólo en momentos excepcionales y con un declarado afán polémico. Su arquitectura tiene poco que ver con lo clásico y mucho con la tradición. El pasado inmediato no le interesa, pero el peso de la tradición figurativa le obsesiona: cuando utiliza citas no lo hace sólo para declarar simbólicamente el poder de la metáfora en un contexto nuevo. Del pasado no le interesa la tradición de Schinkel sino el trabajo artesanal que esconde la imagen formal y, sobre todo, la "ejemplaridad del dórico" como forma pura, y son numerosas las ocasiones en las que lo utiliza, desde las columnas de la casa de Michaelerplatz de Viena, construida en 1911, hasta su espectacular proyecto para el Chicago Tribune ${ }^{35}$, de 1922, donde todo el edificio es una cita, una enorme columna dórica de granito negro, que se presenta, a la vez, como una declaración limite sobre el vacio

\footnotetext{
${ }^{34}$ Al menos asi definia Herriot, alcalde de Lyon, los trabajos de Garnier en su ciudad. Véase al respecto M. RovigatTI, Tony Garnier, Roma, 1985.

35 El concurso celebrado en 1922 para la construcción de la nueva sede del Chicago Tribune se convirtio en un apasionante discurso sobre la validez de los lenguajes, sobre su eficacia simbólica, al enfrentarse al tema del rascacielos, entendido como monumento, en el interior de la gran ciudad. Los proyectos presentados demostraban lo aleatorio de los lenguajes tradicionales frente a un tema nuevo y esta contradicción iba acompañada de todo un desfile de imágenes inverosimiles: pirámides escalonadas, motivos decorativos desarrollados en términos gigantescos, estructuras cristalinas de carácter expresionista, columnas egipcias, pirámides y estructuras racionalistas, castillos medievales, estructuras góticas, etc. Sobre este importante acontecimiento es imprescindible la consulta de M. TAFURI, «La montagna disincantata. II grattacielo e la City", en W.AA., La città americana dalla guerra civile al New Deal, Ed. Laterza, Roma-Bari, 1973, págs. 417-550.
} 
simbólico de los signos y como homenaje a una arquitectura pura, ajena a la construcción de la metrópoli.

No todos los arquitectos se sentian atraídos por una simbólica relación dialéctica entre vanguardia y tradición, en la que los distintos usos de los clásico perseguian la construcción de un lenguaje fundamentalmente abierto y significativo. La utilización decorativa de los elementos clasicistas por parte de Behrens estaba en las antipodas de la honestidad compositiva, basada en una correcta utilización de los materiales constructivos, propuesta por Poelzig: composición y lenguaje eran la consecuencia lógica de un atento estudio del tema y de los materiales.

Las polémicas citas de Loos, la sinceridad del Poelzig y las pantallas representativas de Behrens no tenían nada que ver con la crítica clasicista de Tessenow, para quien los materiales, las referencias estructurales y el lenguaje clásico eran la consecuencia de un detallado estudio de la composición. Proporción, simetria y claridad eran los utensilios claves de Tessenov: orden regular, simplificación formal y el interés por la depurada construcción popular se convierten en una espléndida ocasión de hacer de la memoria un eterno presente. Todo ello trazado con una regla lógica que explicaba asi en 1916: "no habriamos comprendido bien lo que quiere decir hacer arquitectura si no hubiéramos amado profundamente a la Simetría...” ${ }^{36}$. El hecho de detener la historia de la arquitectura en sus origenes, como en el Instituto Dalcroze de Hellerau, de 1910, suponia una operación de enorme significado en cuanto no se trataba de paralizar el problema de la mímesis de la cabaña primitiva sino de plantear el momento de la primera invención devolviéndole la claridad compositiva como cualidad permanente. Estamos ante una lección compleja que, desde una distinta concepción del espacio, de la articulación de los volúmenes y de contenido ideológico, supieron apreciar algunos arquitectos racionalistas como H. Meyer o H. Schmidt.

La armonía que pretendía conseguir Garnier entre arquitectura, naturaleza e industria, en una equilibrada relación artificiosa, era mucho más consciente que la intuitiva propuesta de Perret cuando señalaba que «aplicando las leyes de siempre, se hacen cosas modernas sin saberlo". Aún cuando su pionera utilización del cemento armado abría una rica experiencia de posibilidades formales y estructurales, Perret no supo desembarazarse de la tradición Beaux-Arts. Unas veces resolvía las referencias clásicas en ejercicios geométricos depurados -como en la Maison Casandre, construida en Versalles en 1924- y en otras ocasiones los elementos figu-

\footnotetext{
${ }^{36}$ La referencia del texto se encuentra en G. Grassı, La construcción lógica..., op. cit., pág. 116.
} 
rativos eran simplificados, sin perder nunca su carácter -como el Teatro de los Campos Eliseos, de 1911-. Pero es posible que una de las más significativas oportunidades en que Perret demuestra su negativa a eliminar todas las consecuencias de lo clásico aparece en la propuesta, publicada en 1922 en L'llustration, de una ciudad de rascacielos colocados en hilera: la estructura monumental es dividida en diferentes cuerpos que reproducen cada uno de ellos tipologias clásicas, articulando las fachadas en función de la disposición de columnas enormes. Estamos ante un magnífico ejemplo de la indecisión de los repertorios clásicos, utilizados con un sentido tradicional, al enfrentarse con la metrópoli, con nuevos problemas; estos rascacielos constituyen la última ilusión de realizar un tratado de arquitectura con el fin de alejar el peligro de la vanguardia y el antihistorismo de la gran ciudad. Pero en el siglo xx la arquitectura no volverá a construir a partir de un repertorio de formas establecido y el coloquio con la historia sólo podrá realizarse asumiendo la tradición figurativa y tipológica de las vanguardias como elemento clave.

Las diferentes formas de apropiación de la tradición clásica han mantenido un coloquio inseguro con las vanguardias, con el nuevo repertorio figurativo y tipológico. Entendida como una abstracción, la arquitectura se veia sometida a multitud de experimentalismos que se justificaban por referirse insistentemente a elementos y problemas externos a la disciplina: las citas históricas, no sólo clásicas, contaminaban simbólicamente el racionalismo. Sólo la voluntad de someterse a un control técnico e ideológico parecía aportar seguridad, pero dejaba intacta la angustia de la investigación del significado de los lenguajes: Wright podía tomar referencias de Japón, de la cultura maya, o proyectar de nuevo la Torre de Babel; Le Corbusier sometía a una autocrítica histórica las proposiciones del racionalismo, no sólo refiriéndose a elementos clásicos o manieristas, sino a la propia tradición de la multitud de propuestas figurativas de las vanguardias; Mies van der Rohe codificaba un nuevo clasicismo basado en el valor de la pureza constructiva y en una depurada elaboración de los detalles: las columnas, los podios, el carácter acabado del espacio.

La lógica de la metrópoli no acepta los sigrios autobiográficos de los maestros del Movimiento Moderno, los aisla como episodios excepcionales. En este contexto, la cita clásica oscila entre la consideración de objettrouvé y la intención de identificar un posible nuevo orden en el que la memoria no acabó nunca de acomodarse. Volver a pensar la disciplina de una manera autónoma, renunciando tanto a la vanguardia como a la tradición Beaux-Arts y recuperando la idea de la existencia de un clasicismo esencial y originario, se convertía en una tarea prioritaria para muchos arquitectos. El problema de la ciudad tiene que ser despejado silenciándolo: en ella sólo caben arquitecturas construidas como discursos sobre la 
forma. En un sentido emblemático podríamos señalar dos momentos singulares en la configuración de esta nueva manera de valorar el clasicismo. Por un lado, el silencio metafísico de las arquitecturas pintadas ${ }^{37}$ por Giorgo de Chirico: la recuperación de la perspectiva constituye el medio más idóneo para ordenar el pensamiento. Las formas clásicas depuradas, los arcos, las columnas, las galerías, las calles y las plazas aparecen como elementos claves de un discurso sobre la arquitectura, en el que la memoria no se propone como modelo sino como meditación.

El clasicismo de De Chirico parece referirse a un esencialismo formal, su arqueologismo ${ }^{38}$ no es disciplinar y la reutilización de la perspectiva sirve para recuperar la arquitectura y el espacio. Él mismo señalaba, en 1920, que el "clasicismo no consiste en asociación, sino en limpia y en poda: reducir el fenómeno, la apariencia primera a su esqueleto, a su signo, al símbolo de su inexplicable existencia". El discurso de De Chirico sobre la forma arquitectónica se realiza a partir de una valoración metafísica del silencio y, aunque su influencia sobre la imagen de la arquitectura fue enorme, su manipulación de lo clásico y de un ambiguo carácter mediterráneo de la ciudad no podia competir con una meditación sobre la autonomia y especificidad de la arquitectura como la propuesta en la efectiva construcción de edificios que no mantienen ocultos los símbolos. Y esto ocurre en el segundo de los momentos emblemáticos a los que nos referíamos más arriba.

En efecto, estamos no sólo ante un momento histórico sino ante un lugar simbólico: el cementerio. En él se dan algunas de las más importantes propuestas intelectuales sobre el problema de la forma y de la tipologia, entendidas como un silencio ante la metrópoli. Y qué mejor lugar para ensayar todo un nuevo discurso, en relación dialéctica con el racionalismo funcionalista de la gran ciudad, que el cementerio, entendido como un espacio "disciplinar" frente al tejido urbano ${ }^{39}$.

Como ejemplos de esta interesantísima alternativa, basada en una valoración autónoma de la disciplina, hemos elegido tres edificios que proponen otras tantas meditaciones teóricas sobre el clasicismo y sobre la memoria tratando de encontrar la razón de la arquitectura. En esos edificios se plantea un definitivo alejamiento de la tradición academicista y

${ }^{37}$ Es interesante ver Paolo BALDACCl, "Le classicisme chez Giorgo de Chirico", en Cahiers du Musée National d'Art Moderne, núm. 11, 1983, págs. 18-31.

${ }^{38}$ En relación al tema de la perspectiva de De Chirico y a la utilización de motivos de la pintura romana, véase Maurice OWEN, "Giorgo de Chirico et la perspective metaphisique", en Cahiers du Musée National d'Art Moderne, núm. 11, 1983, págs. 33-53.

${ }^{39}$ En relación a esta idea véase Georges TEYssot, "Frammenti per un discorso funebre. L'architettura come lavoro di lutto", en Lotus international, núm. 38, 1983, págs. 5-17. 
Beaux-Arts y del Movimiento Moderno y, significativamente, los temas de la tradición clásica que retoman coinciden con los últimos intereses de la historia del arte: la llustración y el Manierismo. Es asi como podemos entender la profunda investigación sobre los lenguajes propuesta en la Capilla Woodland, de Asplund, y en la Capilla de la Resurrección, de Lewerentz, en el cementerio Woodland de Estocolmo (1935-40) y en el "baldaquino de las despedidas" y la Capilla de las Plegarias de J. Plěcnik en el Cementerio de Lubiana (1938-40).

Las obras de Asplund y Lewerentz surgen en el contexto de lo que $D$. Porphyrios ${ }^{40}$ ha denominado neodórico escandinavo con la intención de definir una búsqueda que en su afán por acercarse al origen de lo clásico tiene que pasar necesariamente por la atracción hacia la arquitectura de la llustración y, en ese sentido, la capilla Woodland ${ }^{41}$ de Asplund plantea una sintesis entre el mito de la cabaña primitiva y la idea del templo originario, ofreciendo una particular visión de la idea de mímesis que ya no tiene relación con la naturaleza y sí con la historia de la arquitectura. Pero donde se afirma el carácter intelectual, artificioso y erudito es en la capilla de Lewerentz y, sobre todo, en la obra de Plěcnik ${ }^{42}$ : el lenguaje clásico se descodifica, los órdenes y frontones mantienen un diálogo crítico para hacer más expresiva la autonomia de la disciplina: el juego de tamaños y la dislocación del orden es la excusa para devolver la especificidad al proyecto, para convertirlo en forma de conocimiento.

La poética manierista alcanza, en estos ejemplos, un valor silencioso, conscientemente apartado del caos metropolitano y de compromisos revolucionarios. Una meditación disciplinar sobre el lenguaje manierista que no puede relacionarse exclusivamente con la idea de una memoria abstracta del manierismo como composición, atribuido por Rowe $\mathrm{H}^{43}$ a algunas obras de Le Corbusier y, muchos menos, al malabarismo ahistórico definido por Charles Jencks al proponer -en la idea de un eterno retorno de los estilos y las formas- la existencia de un nuevo manierismo con respecto al Movimiento Moderno, que ha denominado Late-Modern ${ }^{44}$.

40 D. Porphygios, Clasicism is not a Style, Londres, 1982.

${ }^{41}$ Sobre las dos capillas del cementerio Woodland véase D. Porphyrios, "Clássico, cristiano, socialdemocratico. L'architettura funebre di Asplund e Lewerentz", en Lotus International. $\mathrm{n}^{\circ} 38,1983$, págs. 71-77.

4) La interesantisima experiencia del cementerio de Plecnik puede verse en Marco PozzE TTO, “Zâle: obitorio giardino. Jozě Plečnik, Lubiana, 1938-40", en Lotus international, núm. 38, 1983, págs. 107-111.

43 Las relaciones entre Palladio y Le Corbusier $y$, en general, entre el Manierismo y el Movimiento Moderno han sido estudiadas en dos magníficos trabajos de C. Rowe: «Las matemáticas de la vivienda idea|» y "Manierismo y arquitectura moderna", recogidos ambos en Manierismo y arquitectura moderna y otros ensayos, op, cit., págs. 9-90.

${ }^{44}$ Una interesante critica a los conceptos de Late-Modernista y Post-Modernism se en- 


\section{LA COLUMNA, LA VILLA, LA CIUDAD}

La cita clásica, aislada de la ciudad funcionalista y de la arquitectura racionalista -aunque en permanente intercambio de significados y valores- y obligada a una silenciosa operación disciplinar, pretende entablar una relación dialéctica con el Movimiento Moderno en la construcción de la ciudad. Las permanencias urbanas, la adecuación al ambiente histórico y una nueva valoración de lo representativo, del monumento, justifican el nuevo experimentalismo con el lenguaje del clasicismo que ponen en marcha algunos arquitectos para librar la batalla con el racionalismo en la metrópoli.

Los distintos modos de hacer referencia a lo clásico que hemos señalado -y los ejemplos podrian multiplicarse- parecian plantearse siempre como ensayos, como trabajos de laboratorio, como ilustraciones de un tratado de arquitectura imposible. Sin embargo, en el momento en el que todas esas indecisiones tienen la oportunidad de enfrentarse con la ciudad parecen adquirir una cierta seguridad. Tipo, naturaleza e historia se aúnan en un enorme esfuerzo por reconstruir la experiencia histórica de las tipologias en la ciudad, sin olvidar las nuevas condiciones ideológicas y técnicas. Al buscar una articulación entre los lenguajes y los tipos no lo hacen desde la atracción por una emulación de los modelos, sino desde la idea de recuperar el prestigio histórico de las tipologias y de las formas, queriendo volver a utilizar su peculiar significación en la construcción de la ciudad. Los dos casos en los que estas ideas abrieron paso a un apasionante debate se configuran en un enfrentamiento con el constructivismo soviético, por un lado, y con la tradición futurista y racionalista italiana, por otro.

Si es cierto que muchas de esas arquitecturas respondian a la voluntad ideológica de construir espacios jerárquicos y monumentales que expresasen simbólicamente la imposición del poder, fascista o estalinista, también hay que advertir que los problemas planteados fueron decisivos para el debate arquitectónico.

En la Unión Soviética muchos arquitectos de la vanguardia se sintieron permanentemente atraídos por el peso del clasicismo, entendido no sólo como cita. Recordemos el proyecto de Melnikov, de 1919, para un crematorio, o el espléndido proyecto de los hermanos Vesnin para el complejo del Narkomtjazprom de Moscú en 1934, que se presenta como una

cuentra en M. Luisa Scalvan,, "Prima e dopo il Post-Modernism", en Op. cit., 1980, págs. 5-28. 
inteligente sintesis de tipologias y formas diferentes. Esa relación con la historia del clasicismo se enriquece constantemente recurriendo a motivos y tipos que han sido siempre objeto de la meditación sobre la memoria, sobre los orígenes de la arquitectura, tal vez por su carácter excepcional y limite en relación a la teoría. En este sentido, es interesante recordar la galeria de columnas del proyecto, realizado por V.F. Krinski en 1948, para una ciudad de artistas; el tema iluminista del túnel, tal como lo entiende Fomin en algunas estaciones del metro de Moscú, o la sugestiva idea de citar el singular templo romano de Baalbek para una estación del mismo metro en un proyecto de L. Teplickij de $1934^{45}$.

En Italia el debate es enormemente complejo y rico, pero podriamos resumirlo señalando que un nuevo espiritu clásico comprometió los lenguajes, los tipos y las ciudades; con distintas versiones que iban desde el silencio metafísico de De Chirico o Savinio -el arte como memoria- a las citas manieristas de una excepcional "arquitectura de la ciudad" como es la Ca'Bruta de Muzio, pasando por la, aparentemente, inverosímil polémica entre Piacentini y Ojetti sobre el uso del arco y la columna, y por el clasicismo racionalista de Terragni ${ }^{46}$. La instrumentalización ideológica y la abstracción y extrañamiento de la arquitectura desvelaron toda la inseguridad del clasicismo y del racionalismo en el símbolo monumental del EUR.

Después de las dispares alusiones a las formas del clasicismo, a los tipos sancionados por su representatividad, después de todas las meditaciones disciplinares, después de Mies y de Le Corbusier, la ciudad y su arquitectura se enfrentan a una tregua inestable con enemigos fantasmagóricos, con una indecisión formal que confunde el proyecto y el lenguaje. El coloquio con la historia se hace imprescindible pero nunca ha sido tan inseguro: Kahn, Johnson, Stirling, lo vernáculo, el populismo, no son sino sintomas de una aspiración rota, enajenada, por controlar la forma. Las utopias tecnológicas, las complejas megaestructuras y la ciencia son un espejismo.

Por otra parte, el legado del Movimiento Moderno condiciona cualquier respuesta. Es al mismo tiempo demasiado rico y demasiado miserable, pero inevitable. En este contexto no resulta sorprendente que los intentos de clarificación provengan de una nueva y rigurosa relación entre

\footnotetext{
4s Sobre la Union Soviética es imprescindible la consulta del volumen coordinado por J.L. COMEN, M. DF MiChelis y M. TAFURI, URSS 1917-1978: la ville, larchitectture, Roma-Paris, 1979.

${ }^{46}$ La bibliografia sobre el caso italiano es abundantísima. Aqui sólo mencionaremos, por su utilidad, la selección de textos realizada por L. PATEITA, L'architettura in Italia. 1919-1943. Le polemiche, Clup, Milán, 1972.
} 
racionalismo y clasicismo. Aldo Rossi, Giorgio Grassi, Massimo Scolari, entre otros, inician la operación de limpieza, de reconstrucción: es la arquitectura la que tiene que controlar la construcción de la ciudad, asumiendo la lección de la historia urbana, de los tipos comprobados colectivamente. La historia entra nuevamente en el momento del proyecto, pero sometida a una espectacular reducción: del tipo no interesa la función y los problemas del lenguaje y de la forma no pueden repetir ni la experiencia de Le Corbusier ni la de la cita clásica.

Al recuperar la especificidad de la disciplina, al proclamar su autonomía de cualquier contaminación, se hace desde la idea de la racionalidad del método. La historia de la disciplina se despoja de la memoria de los lenguajes y eso implica reducir la arquitectura a un vacío formal, a una construcción lógica. Su capacidad de significación sólo pede estar en la consecuente relación con la ciudad histórica: son los usos colectivos de las formas urbanas los que llenarán de contenido las tipologias y el vacío formal. De ahí el interés por recuperar la idea de monumento, de la calle tradicional, de la plaza, etc. Dei clasicismo les interesan los límites de la forma, la idea de orden tipológico, la codificación de un lenguaje. Pero esta última ha sido, precisamente, una aspiración nunca conseguida por el repertorio clásico.

«El progreso -señalaba Massimo Scolani- no es novedad y cambio, o por lo menos no los presupone necesariamente; progreso es, en todo caso, clarificación, paso de lo complicado a lo sencillo. En la arquitectura significa simplicidad, unidad, simetría y proporciones justas, claridad tipológica, homogeneidad entre planta y alzado, y negación del desorden, aunque este se justifique como reproducción simbólica de la crisis de una cultura ${ }^{47}$. La búsqueda, aún más radical, de un nuevo orden lógico lleva inexcusablemente a un compromiso mayor con el clasicismo: "Las reglas clásicas -como indica G. Grassi ${ }^{48}$ - constituyen un sistema lógico de relaciones entre los elementos de la arquitectura, pero son también un auténtico "universo lógico» de la experiencia de la arquitectura».

Esta rigurosa y clarificadora meditación sobre la arquitectura y la ciudad llevaba en su interior dos equivocos de consecuencias imprevisibles. Por un lado, el difícil e impreciso límite con una valoración intimista de lo urbano en la que las funciones asignadas a la arquitectura fueron esencialmente retóricas, como de hecho ha ocurrido con Rob Krier, quien planteaba su idea de la ciudad en los siguientes términos: "La geometría de la

47 Massimo SCOLARI, "Vanguardia y nueva Arquitectura", en W.AA, Arquitectura racional, Alianza, 1979, pág. 202.

${ }^{48}$ G. Grassi, La construcción lógica..., op, cit., pág. 117 
casa individual extrae su fuerza del contraste con la naturaleza viviente. Cuanto mayor sea la densidad y el número de casas, mayor será el desplazamiento de la naturaleza y el entorno, y por lo tanto más importantes se vuelven los espacios artificiales, que atraviesan la ciudad como canales. Las calles y las plazas son los vehículos de la vida pública, mientras las silenciosas células en forma de patios son lugares de refugio, intimidad y retiro. La arquitectura de edificios residenciales y de oficina debe ser normal y decorosa. Sólo los edificios monumentales necesitan de una magnificencia especifica» ${ }^{49}$.

El otro equívoco lo constituye el hecho de que introducir la historia en el proyecto supone, por mucho que se insista en rechazar la idea de eclecticismo, caer en la tentación del lenguaje, de la forma, como memoria. $Y$ en esa meditación sobre la forma no es de extrañar que se planteen de nuevo los problemas del origen, de la invención del clasicismo. De esta manera Gerd Neumann podia proponer, en 1980, y cual nuevo Calímaco, un capitel corintio imaginario en el que las célebres hojas de acanto ondean al viento; $O$. Mathias Ungers reproducia el proceso del origen de los órdenes, en la Bienal de Venecia de $1976^{50}$, colocando la serie del tronco, palo, montante, y columna; Quilan Terry construia la cabaña primitiva en unos jardines de Hampshire en 1980; y, por qué no, este interés por la especificidad clásica ponia de actualidd temas tipológicos tan atractivos a lo largo de la historia como las villas de Plinio el Joven: arquitecturas literarias y arquitecturas de papel ${ }^{51}$ inician un nuevo discurso sobre el clasicismo, como se puede ver en las diferentes reconstrucciones de las villas de Plinio propuestas por Fernando Montes, Bernard Huet o León Krier ${ }^{52}$.

Juegos intelectuales con el clasicismo o nostalgia por recuperar el significado cultural de la memoria, el hecho es que Stanley Tigerman ha proyectado, en 1980, una casa inspirada en la Villa Madama; Thomas Gordon Smith ha construido la Laurentina y la Tosacana en California, en 1979, y Thomas Beeby ha dibujado la Casa de Virgilio. En este marco la tentación de los eclecticismos más arbitrarios y la rigurosa meditación sobre la forma se confunden: arquitecturas clásicas fluorescentes como las de Charles Moore; motivos del Sant'Ivo de Borromini convertidos en edificios asistenciales por Portoghesi, o la "Strada Novissima" de la Bienal de

49 R. KRIER, Sobre la arquitectura, op. cit., pág. 25.

so Véase el interesante catálogo de la Bienal de Venecia de 1976 con el título de Europa America. Architetture urbane, alternative suburbane, Venecia, 1978.

51 Véase, en un sentido general, la recopilación de $V$. Magnano Lampugnani, Dibujos y textos de la arquitectura del siglo XX. Utopia y realidad. Ed. Gustavo Gili, Barcelona, 1983.

52 Ver al respecto W.AA. Ut pictura poesis. La Laurentine et l'invéntion de la villa romaine, Ed. Moniteur, Paris, 1982. 
Venecia de 1980 , con fachadas clásicas y barrocas, con columnas salomónicas, serlianas, o el irónico juego sobre los órdenes propuestos por Hans Hollein, nos hablan de una nueva pasión por los lenguajes.

Aunque son tantas las caricaturas y los maquillajes que la poética de la memoria parece, en ocasiones, haberse convertido en la ocasión más atractiva para hacer de la cita decoración -como en las interesantes arquitecturas pintadas sobre arquitecturas reales de Richard Haas ${ }^{53}$ o escenografía.

En todo caso, el panorama de posibilidades figurativas es amplísi$\mathrm{mo}^{54}$. Esta es sólo una de las posibles parábolas del clasicismo.

${ }_{53}$ Véase Richard HaAs, An architecture of illusion, Ed. Rizzoli, Nueva York, 1981.

${ }^{54}$ Sobre la complejidad de la situación actual véanse K. Frampton, Modern Architecture and the critical present, Architectural Design, Nueva York, 1982, S. MARCHAN, La "Condición postmoderna" de la arquitectura, Universidad de Valladolid, Valladolid, 1981, y P.L. BRUSAS. CO, Archittetura antimoderna. La Resistible ascesa della nuova accademia, Florencia, 1984. Un interesante repertorio de imágenes se encuentra en el número $5 / 6$ de $A . D$. dedicado al Post-Modern classicism, 1980. 

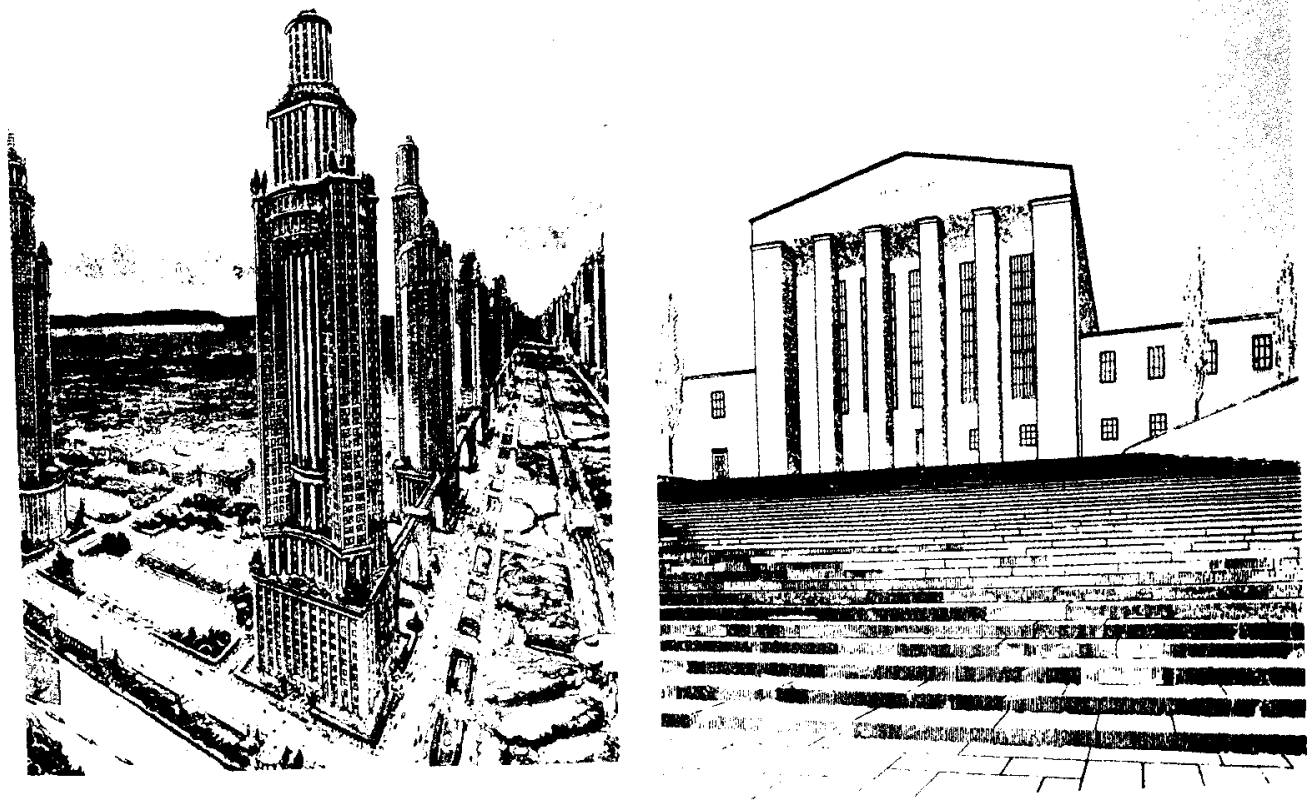

Fig. 1. A. Perret, Torres para Paris, 1922. Fig. 2. H. Tessenow, Instituto Dalcroze, 1910. 1

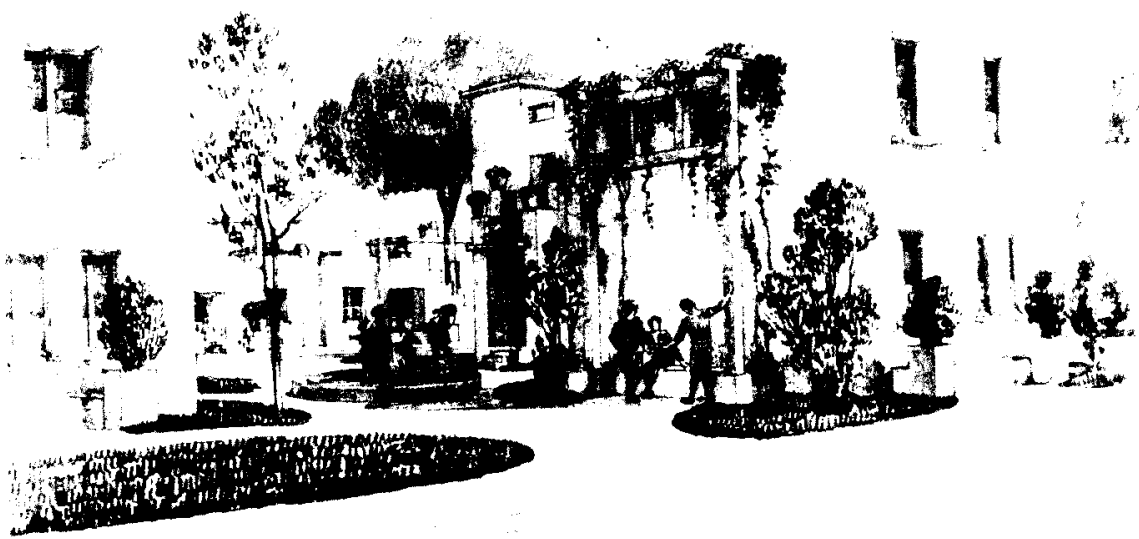

Fig. 3. T. Garnier, La Ciudad Industrial, 1904. 


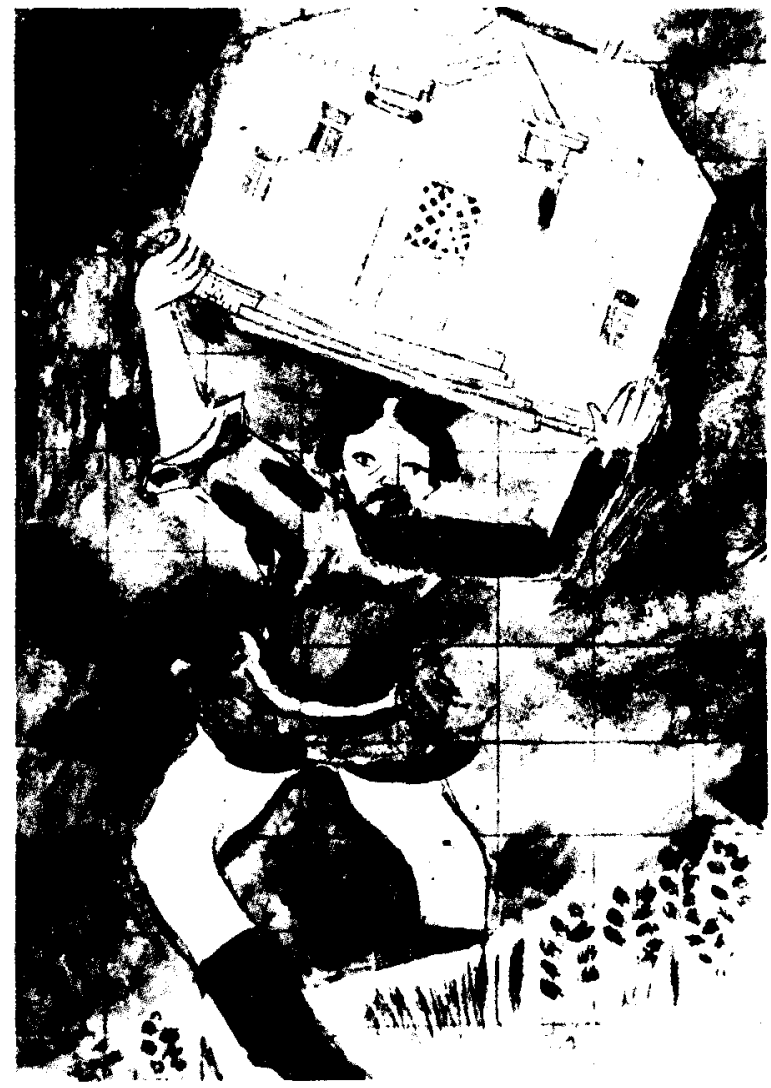

Fig. 4. Chagall, Paz a las cabañas, guerra a los palacios, 1919

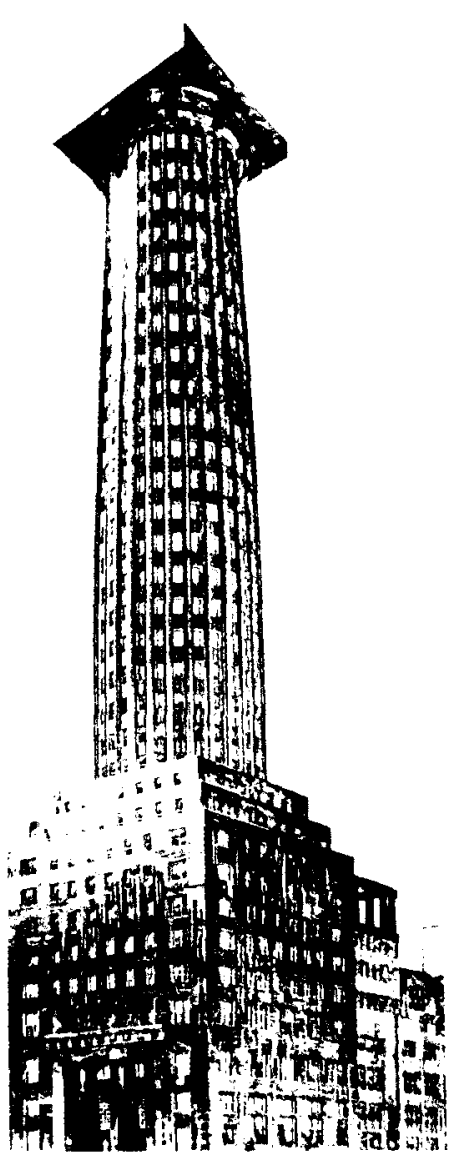

Fig. 5. A. Loos, Chicago Tribune, 1922.

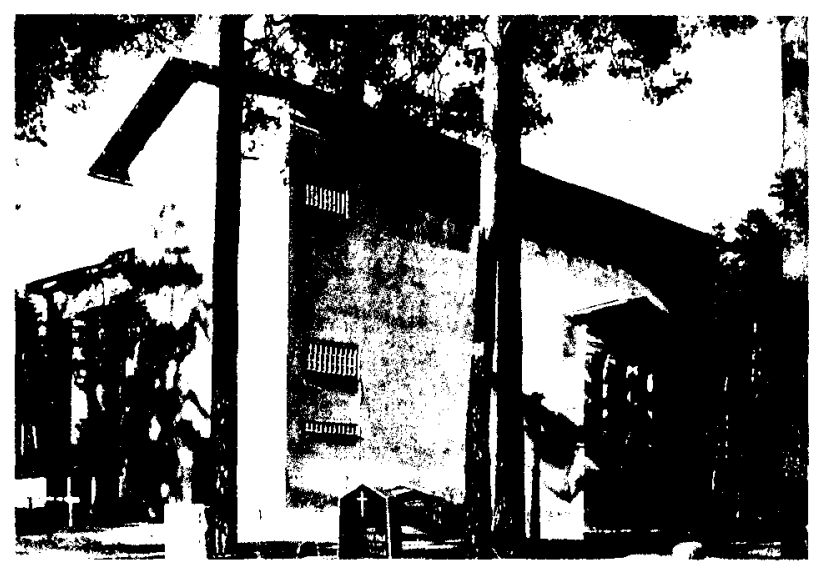

Fig. 6. S. Lewerentz, Capilla de I Resurrección en el Cementerio Woodland. 

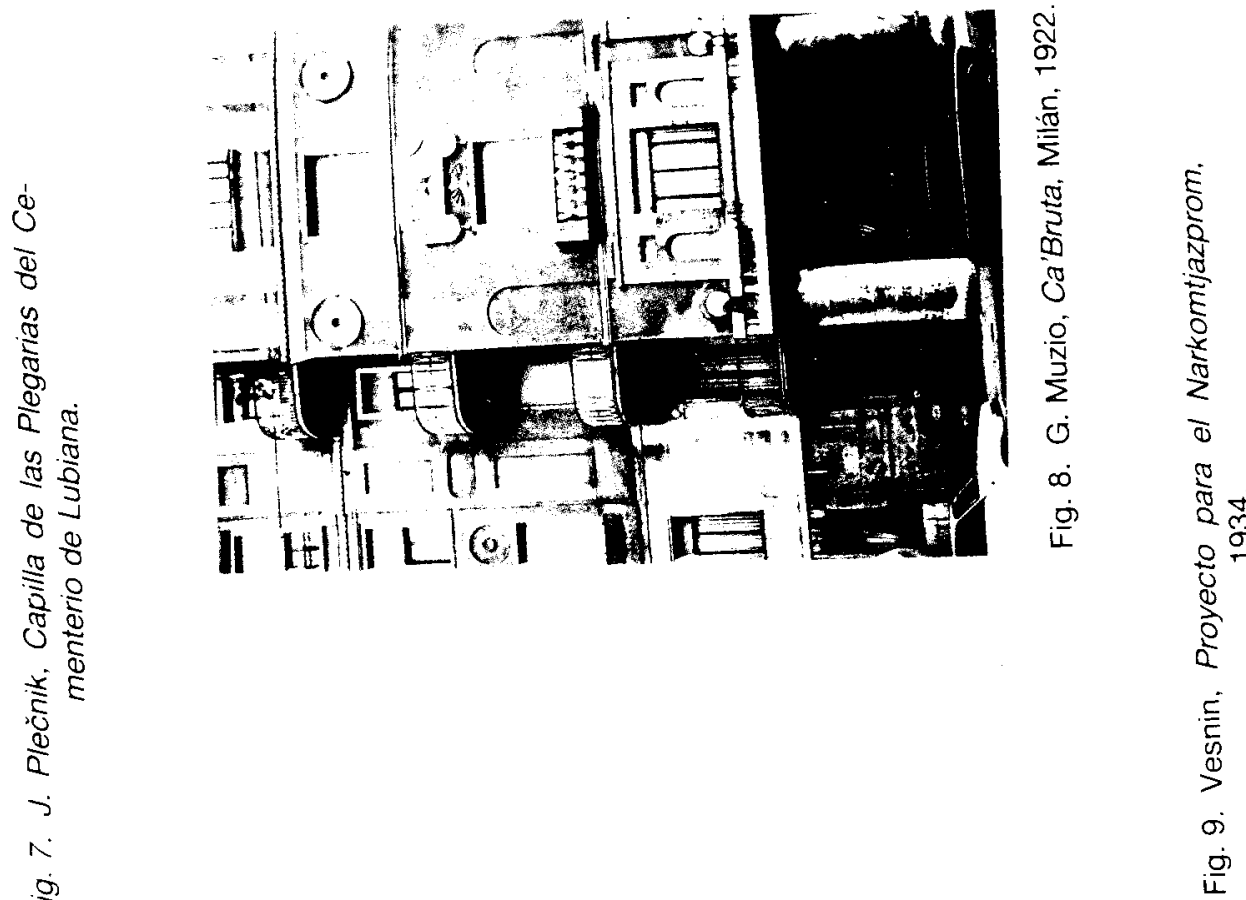

is
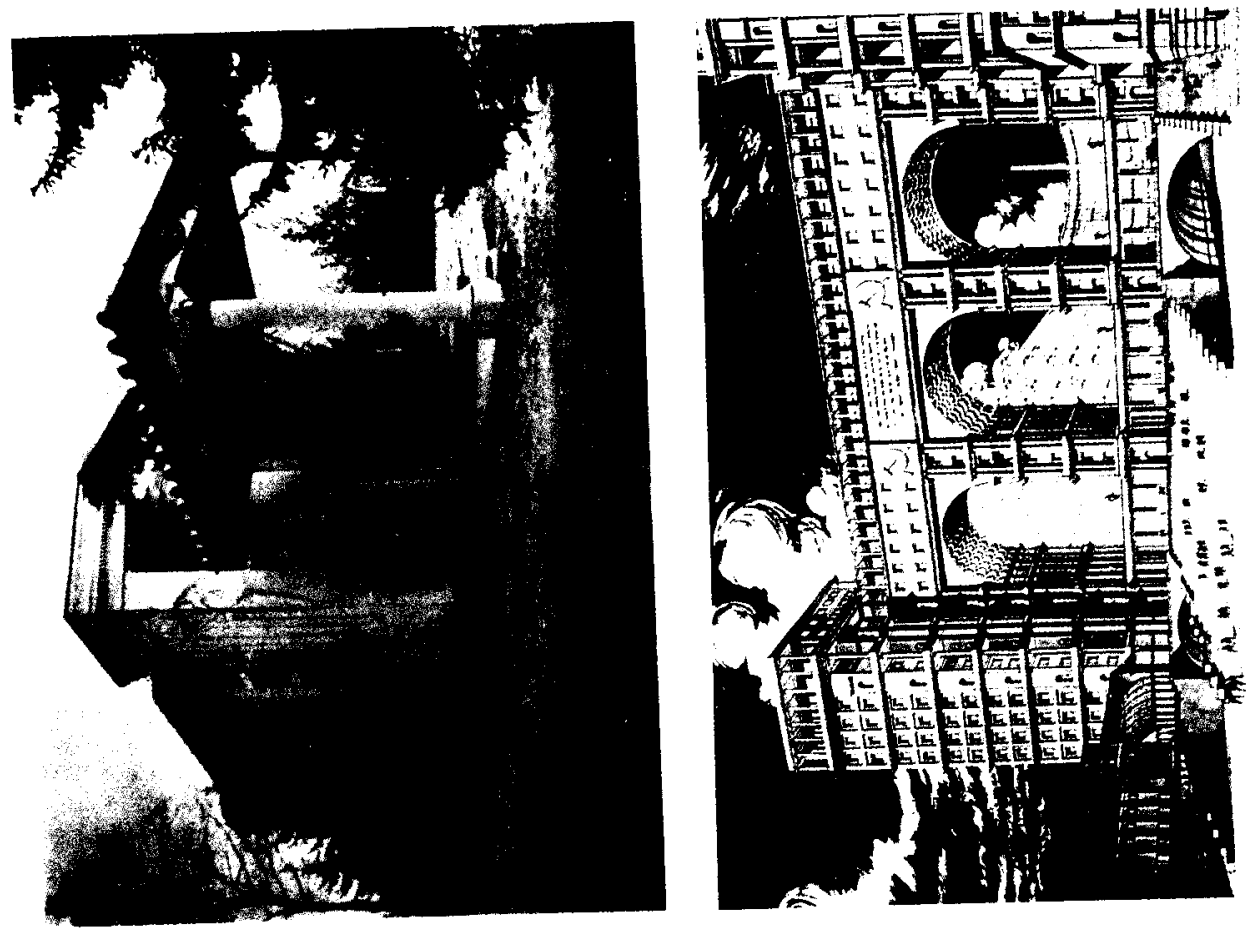


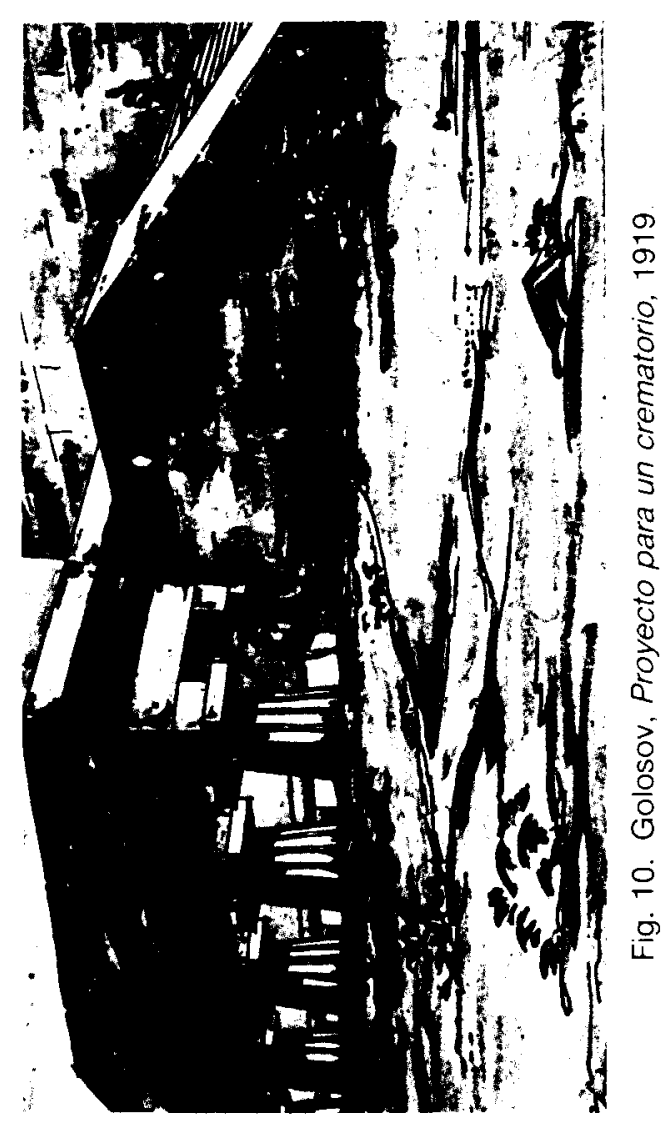

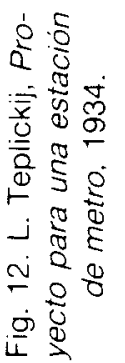
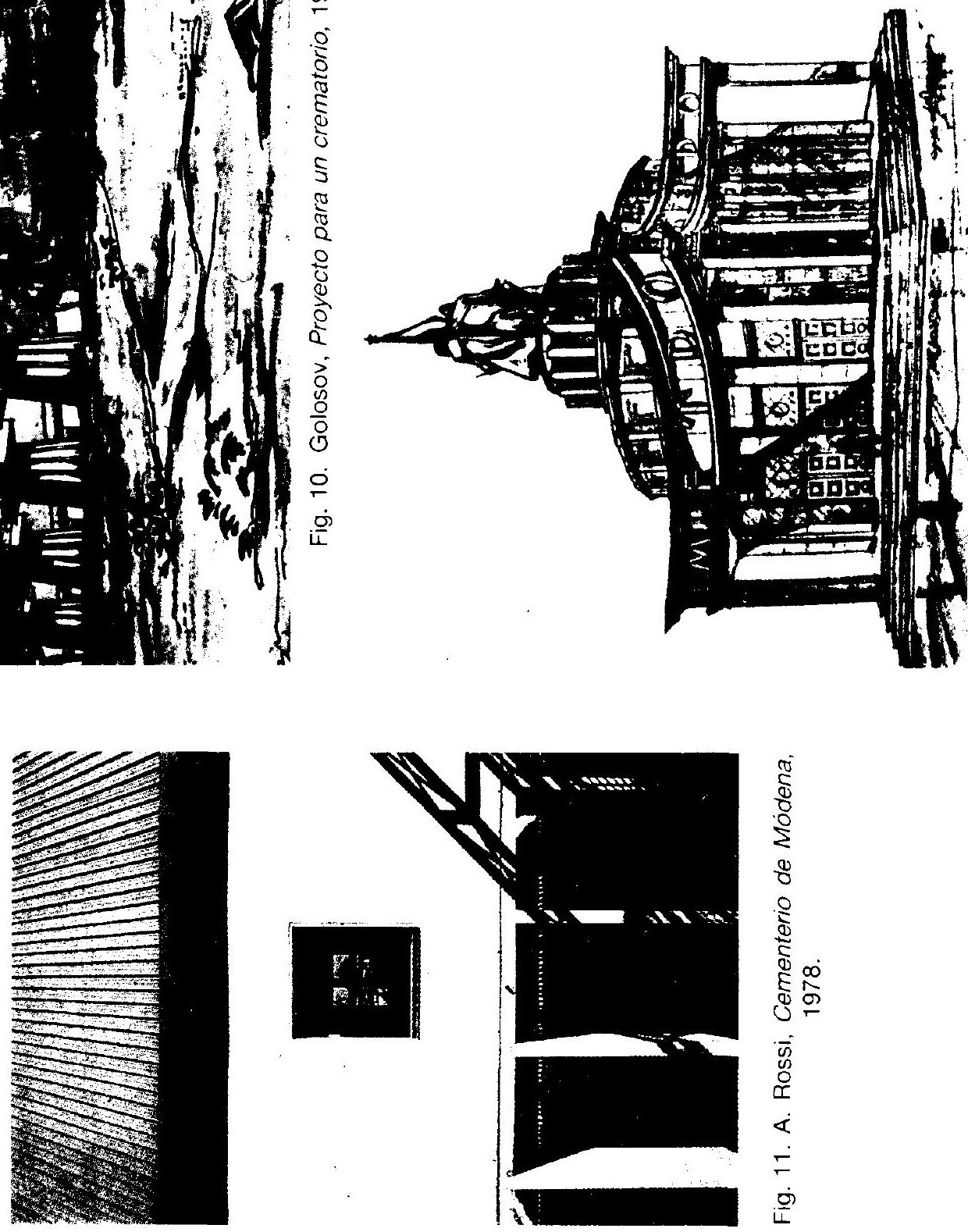


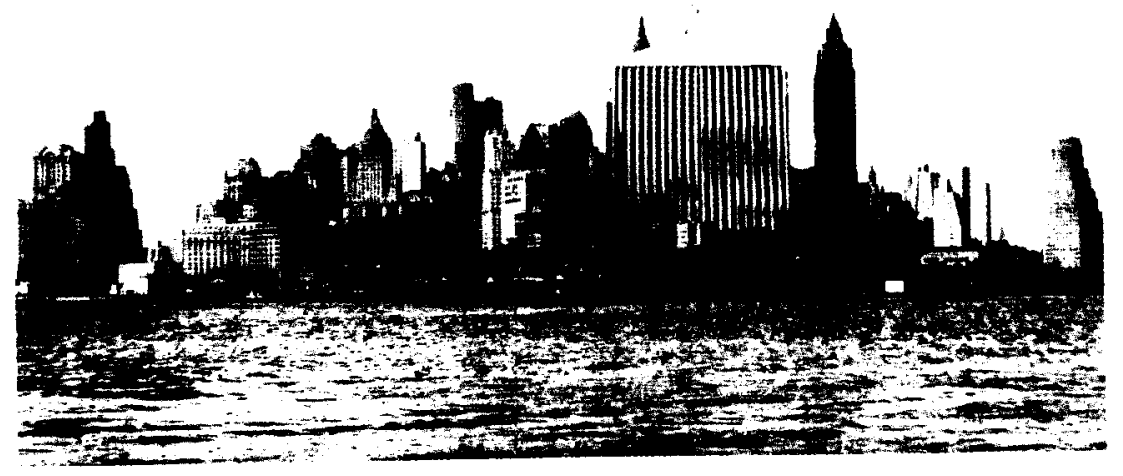

Fig. 13. H. Hollein, El radiador del Rolls Royce en Wall Street, 1966.

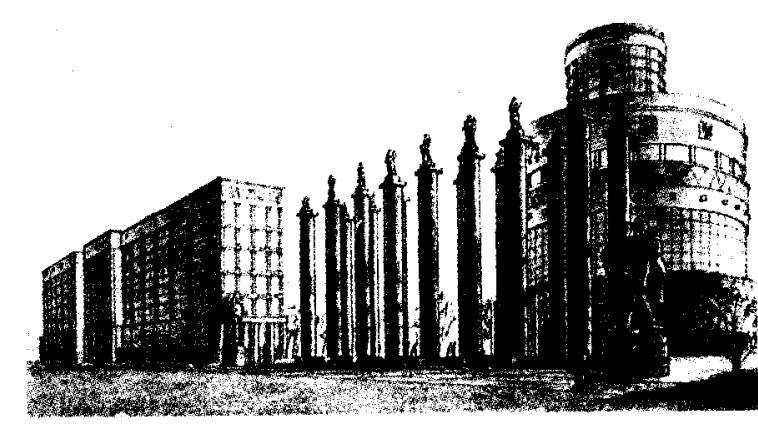

Fig. 14. El Krinskij, Proyecto para una ciudad de artistas, 1948.

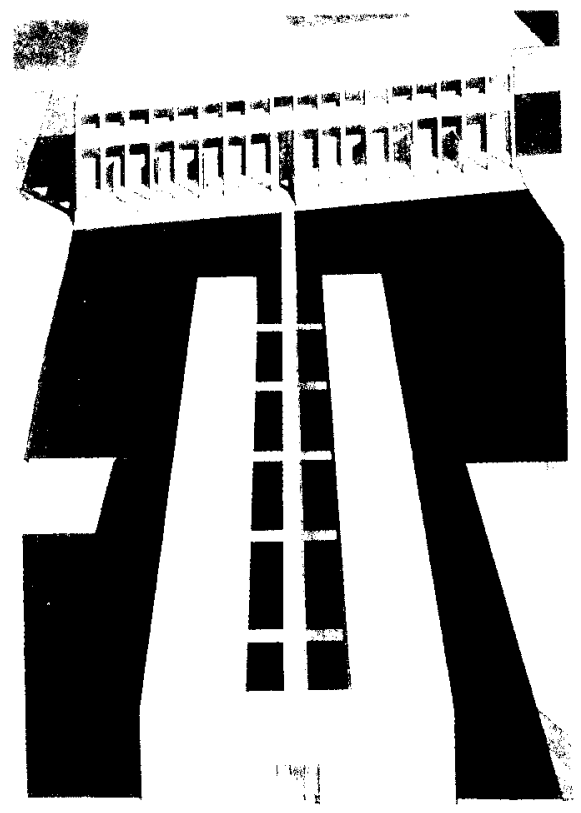

Fig. 15. G. Grassi, Unidad residencial San Pietro, 1972. 

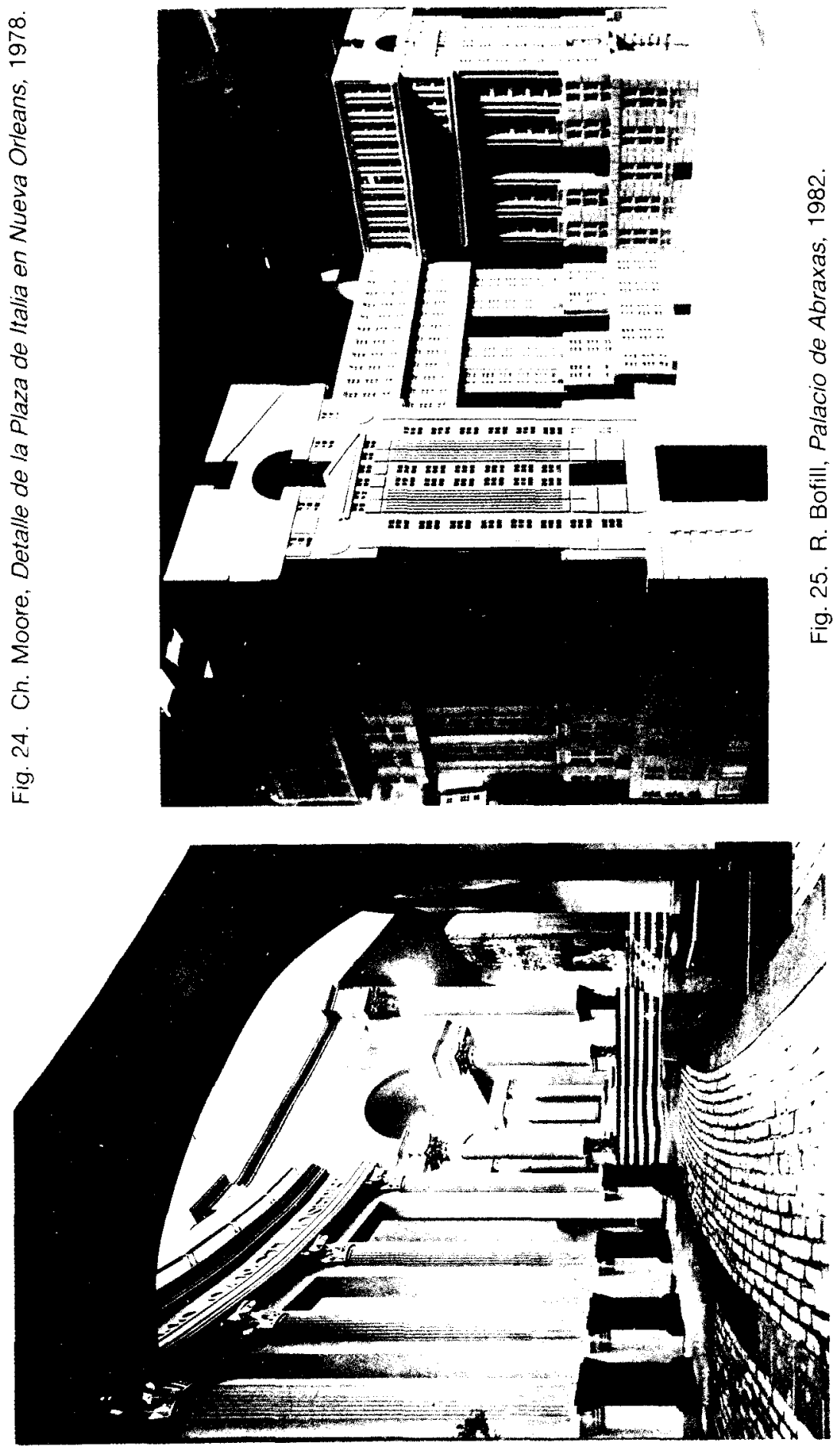